\title{
Groundwater ages, recharge conditions and hydrochemical evolution of a barrier island freshwater lens (Spiekeroog, Northern Germany)
}

\author{
Tania Röper ${ }^{\mathrm{a}, *}$, Kerrin F. Kröger ${ }^{\mathrm{a}}$, Hanno Meyer ${ }^{\mathrm{b}}$, Jürgen Sültenfuss ${ }^{\mathrm{c}}$, Janek Greskowiak ${ }^{\mathrm{a}}$, \\ Gudrun Massmann ${ }^{\mathrm{a}}$ \\ a Department of Biology and Environmental Sciences, Carl-von-Ossietzky University of Oldenburg, Ammerländer Heerstraße 11, D-26129 Oldenburg, Germany \\ ${ }^{\mathrm{b}}$ Alfred Wegener Institute, Telegrafenberg A43, D-14473 Potsdam, Germany \\ ${ }^{\mathrm{c}}$ Institute of Environmental Physics, University of Bremen, Otto-Hahn-Allee, D-28359 Bremen, Germany
}

\section{A R T I C L E I N F O}

\section{Article history:}

Received 7 February 2012

Received in revised form 25 May 2012

Accepted 7 June 2012

Available online 15 June 2012

This manuscript was handled by Laurent

Charlet, Editor-in-Chief, with the assistance

of Peter Wolfgang Swarzenski, Associate

Editor

\section{Keywords:}

Island hydrology

Stable isotopes

Hydrochemistry

Environmental tracer

${ }^{3} \mathrm{H}-{ }^{3} \mathrm{He}$ dating

\begin{abstract}
S U M M A R Y
Freshwater lenses below barrier islands are dynamic systems affected by changes in morphodynamic patterns, groundwater recharge and discharge. They are also vulnerable to pollution and overabstraction of groundwater. Basic knowledge on hydrogeological and hydrochemical processes of freshwater lenses is important to ensure a sustainable water management, especially when taking into account possible effects of climate change. This is the first study which gives a compact overview on the age distribution, recharge conditions and hydrochemical evolution of a barrier island freshwater lens in the southern North Sea (Spiekeroog Island, Eastfrisian Wadden Sea). Two ground- and surface water sampling campaigns were carried out in May and July 2011, supplemented by monthly precipitation sampling from July to October. ${ }^{3} \mathrm{H}-{ }^{3} \mathrm{He}$ ages, stable oxygen and hydrogen isotopes and major ion concentrations show that the freshwater lens reaches a depth of $44 \mathrm{mbsl}$, where an aquitard constrains further expansion in vertical direction. Groundwater ages are increasing from 4.4 years in $12 \mathrm{mbsl}$ up to $>70$ years at the freshwater-saltwater interface. Stable isotope signatures reflect average local precipitation signatures. An annual recharge rate of $300-400 \mathrm{~mm}$ was calculated with ${ }^{3} \mathrm{H}-{ }^{3} \mathrm{He}$ data. Freshwater is primarily of $\mathrm{Na}-\mathrm{Ca}-\mathrm{Mg}-\mathrm{HCO}_{3}-$ and $\mathrm{Ca}-\mathrm{Na}-\mathrm{HCO}_{3}-\mathrm{Cl}$ type, while lowly mineralized precipitation and saltwater are of $\mathrm{Na}-\mathrm{Cl}$ types. A trend towards heavier stable isotope signatures and higher electric conductivities in the shallower, younger groundwater within the freshwater lens may indicate increasing atmospheric temperatures in the last 30 years.
\end{abstract}

(c) 2012 Elsevier B.V. All rights reserved.

\section{Introduction}

Barrier islands are typically characterized by underlying freshwater reservoirs. They develop as precipitation continuously infiltrates into the often highly permeable sediments while displacing the saltwater. Due to density-differences, dispersion and molecular diffusion a freshwater reservoir develops until it reaches hydrodynamic equilibrium with the underlying saltwater (Beukeboom, 1976). The transition zone, the so-called freshwater-saltwater interface, normally is not a sharp interface but a mixing zone of up to several tens of meter thickness (Stuyfzand, 1993).

Freshwater lenses commonly provide drinking water for the public water supply on barrier islands. Moreover, public water supply and island ecosystems strongly depend on a balanced hydrological system. Freshwater lenses are among the most vulnerable aquifer systems in the world due to frequent natural and ever-present anthropogenic threats as mentioned by White

\footnotetext{
* Corresponding author. Tel.: +49 4417983289.

E-mail address: tania.roeper@uni-oldenburg.de (T. Röper).
}

and Falkland (2009). An island's freshwater reservoir is controlled by both natural and anthropogenic factors. Natural factors are the island's stratigraphy, elevation and vegetation patterns (Schneider and Kruse, 2005), pine plantations, precipitation and recharge, discharge at the edges of the island and losses by evapotranspiration, the storage capacity as well as mixing with underlying saltwater (White and Falkland, 2009). Anthropogenic factors are mainly abstraction of groundwater, pollution, land reclamation and beach nourishment (White and Falkland, 2009). Rising demands for freshwater and climate change increases the stress on the water resources and ecosystems (Post, 2005). Impacts on ecological systems, e.g. due to sea-level rise or the increase of storm surges, will be most evident on exposed regions like barrier islands. One highly protected ecological system, including several islands, is the Wadden Sea at the Northern German coast, which has been declared a World Heritage Site in 2009. It represents the largest intact system of tidal sand and mud flats and barrier island depositional systems in the world and is a remarkable feature of the recent Holocene development of a sandy coast in terms of rising sea level (CWSS and WHNPG, 2008). Flemming (2002) 
predicts intense morphodynamic adjustments for the southern North Sea in case of an accelerating sea-level rise which would also have an influence on the hydrological system. In fact, sea-level rise with related hydroisostatic subsidence of the North Sea basin and an increase of storm surges are predicted for the future (IPCC, 2007). Hence, detailed knowledge about the recent development and ongoing processes concerning freshwater lenses, e.g. saltwater intrusion or expected shrinkage of freshwater lenses (Post, 2005) are of major importance in order to assess possible future changes and in order to be able to take measures on time.

Detailed studies on the hydrogeology and hydrochemistry of barrier islands were carried out by Beukeboom (1976), Grootjans et al. (1996) and Sival et al. (1997) for the Frisian Islands Schiermonnikoog, Vlieland, Terschelling and Ameland. The East Frisian Islands Langeoog and Norderney were studied in the focus of hydrochemical conditions and groundwater dynamics (Marggraf and Naumann, 2003; Marggraf, 2005). Dune areas as freshwater reservoirs with regard to problems of salinization, freshening, decalcification, atmospheric pollution and artificial recharge have been studied intensely by Stuyfzand (1993). Moreover, analytical solutions exist on the geometry of a freshwater lens (Vacher, 1988; Van der Veer, 1977; Fetter, 1972) as well as travel times within the lens (Vacher et al., 1990; Chesnaux and Allen, 2008.

Still, not much is known about the groundwater ages, recharge rates and hydrogeochemical evolution of Spiekeroogs or similar barrier island freshwater reservoirs. This study combines age dating with ${ }^{3} \mathrm{H}-{ }^{3} \mathrm{He}$, stable isotope and major ion analysis of precipitation, surface water and groundwater in order to generate a compact overview of the hydrological system of a barrier island. The aims of the study were (i) to estimate travel times and recharge rates, (ii) to give an insight on the ground- and surface water origin and recharge conditions and finally, (iii) to generate a conceptual model on the hydrochemical evolution during recharge.

\section{Study area}

\subsection{Geology and geomorphology}

Spiekeroog is part of the Eastfrisian Island chain in front of the North German coastline (Fig. 1). These barrier islands act as a protection from storm surges for the mainland. The island of Spiekeroog has a length of $9.8 \mathrm{~km}$ and a maximum width of $2 \mathrm{~km}$ which results in an approximate area of $21.3 \mathrm{~km}^{2}$. It lies in between the islands of Langeoog and Wangerooge. The islands are separated by the Otzumer inlet in the west and the Harle inlet in the east (Fig. 1). Mean tidal high water reaches $+1.20 \mathrm{~m}$ above mean sea level (masl) and the tidal range is about $2.80 \mathrm{~m}$.

Spiekeroog shows a characteristic trisection into a main dune arc, a salt-marsh at the Wadden Sea side and the eastern part "Ostplate" showing active formation of dunes (Sindowski, 1973). The village is located in the western part, protected by the main dune arc which borders it to the north. The population counts approximately 700 people. 100,000 day tourists and 90,000 overnight tourists visit the island annually (Schade, 2011 pers. comm.). About $0.5 \mathrm{~km}^{2}$ of Spiekeroog are covered by forest.

The formation of the East Frisian barrier islands as they are now positioned, began in the early Boreal (Streif, 1990). According to Barckhausen (1969), this process can be attributed to the interaction of wind, swell and ocean currents. The islands developed from periodically flooded shelves to partly dry barrier beaches and finally to dry dune islands. Their morphological shape is caused by the prevailing westerly winds which supply most sediment. However, the southwestern part of Spiekeroog contains a core of Pleistocene sediments at 5-10 m depth (Streif, 2002, 1990).
The middle and eastern part of the island are underlain by a Pleistocene channel. Its origin is assumed to be a Saalian meltwater valley (Sindowski, 1970). The Holocene North Sea ingression led to erosion and relocation of the sediments in the Harle-channel. Nowadays the channel is filled with Holocene sediments, consisting mainly of middle- to coarse-grained sand, rarely separated by embedded clay lenses. The Holocene base layer is located in 15-20 m below sea level (mbsl) (Sindowski, 1970).

Below the Holocene basis Elsterian glacial sediments were found, mainly consisting of pale, fine- to middle-grained, glaciofluvial sands. Deposits of the Lauenburger Ton, a distinct common clay layer in Northern Germany, have only been proven in a small area in the northeastern part of Spiekeroog and below the tidal flats towards the mainland (Sindowski, 1970). They are underlain by Pliocene sediments, which also consist predominantly of fine- to middle-grained sands. Between 44 and $55 \mathrm{mbsl}$ a clay layer was encountered in several sediment cores (NLfB, 1985). It is assumed to be continuous below the main dune area (OOWV, 2009). Tronicke et al. (1999) suggested the absence of this clay layer southeast of the main dune arc from geophysical measurements.

During its formation, the island shifted about $1.2 \mathrm{~km}$ over its own tidal flat from West to East. From 1650 to 1960 an increase in length of $4.6 \mathrm{~km}$ and in width of $0.6 \mathrm{~km}$ was monitored. This was predominantly caused by the aggradation of sediment in the eastern Harle inlet (Eitner, 1996; Fitzgerald et al., 1984; Sindowski, 1973). To protect the island's west against storms and strong hydrodynamics at the Otzumer inlet, coastal protection activities were initiated in the mid-18th century and continue until today (NLWKN, 2010). This allowed for the dunes to develop further. Older dunes from the mid-16th century are only preserved in the western part of the island (Sindowski, 1970). They form the inner island core, which is surrounded by younger chains of dunes to the North and East (Fig. 1). The youngest, primary dunes adjoin the beach. In the main dune area ground levels reach $25 \mathrm{~m}$ above sea level (masl). Recent dunes on the eastern part are still in a stage of development, comparable to the younger dunes on the western part of the island.

\subsection{Hydrogeology}

Due to the geological structure of the island, two different aquifers and one aquitard can be distinguished. Fine- to coarse-grained Holocene sands, which contain embedded clay lenses, with underlying Pleistocene sand deposits and below finer-grained Pliocene sediments together form an aquifer. At a depth of $44-55 \mathrm{mbsl}$ the sands are underlain by the more or less continuous clay layer, which acts as an aquitard. Underlying Pliocene fine- to middlegrained sands form the second aquifer. The intercalated clay layer divides fresh groundwater from underlying saline groundwater.

Annual precipitation on Spiekeroog from 1988 to 2006 averages $749 \mathrm{~mm}$ (OOWV, 2009). The highest amounts are observed in July and September. Since most of the rainwater rapidly drains into the sediment, hardly any surface runoff exists. Evapotranspiration, measured by a lysimeter (Friedrich-Franzen system), amounts to $113 \mathrm{~mm} / \mathrm{a}$ (OOWV, 2009). Most of the groundwater recharge takes place in the dune areas. Groundwater recharge rates have been estimated on the basis of lysimeter data, the GROWA06v2 model and the area-based analysis of Dörhöfer and Josopait (OOWV, 2009). The lysimeter data accounts for an annual recharge of $636 \mathrm{~mm}$. In contrast, the results from the Growa06v2 model, a large-scale model for Lower Saxony, show a groundwater recharge of $200-300 \mathrm{~mm} / \mathrm{a}$ for the main dune arc (NIBIS Kartenserver, 2011), and is consistent with a groundwater recharge of $220 \mathrm{~mm}$ calculated by Beukeboom (1976). Calculations by Dörhöfer and Josopait (OOWV, 2009) propose a groundwater recharge of 451-500 mm/a, based on the German Soil Map for $50 \%$ of the 


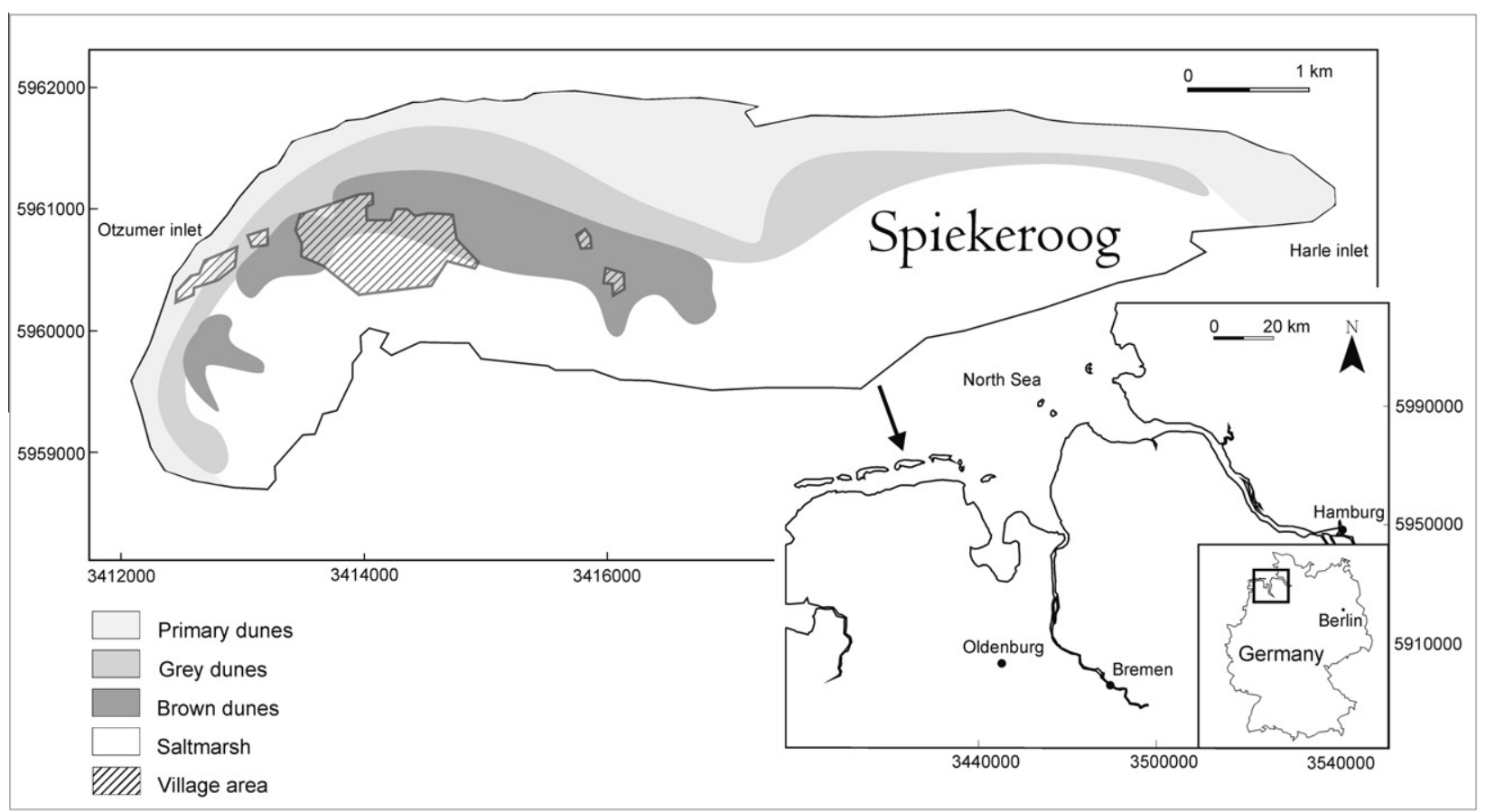

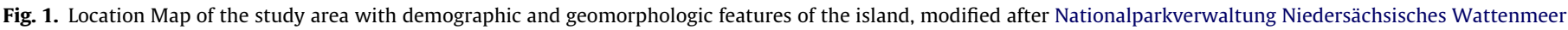
(2011).

catchment area of the production wells, while $30 \%$ receive 401 $450 \mathrm{~mm} / \mathrm{a}$ and 20\% 301-350 mm/a. These estimates coincide with former investigations (NLfB, 1985). Mean groundwater abstraction is $154,000 \mathrm{~m}^{3} / \mathrm{a}$, with $30 \%$ of the volume being withdrawn during the peak tourist season in July and August (OOWV, 2009).

The main freshwater lens of Spiekeroog Island is located below the main dune arc in the western part. Its dimensions were determined first by Sengpiel and Meiser (1981) and later by Tronicke (1997) who assumed the maximum thickness to reach $40 \mathrm{mbsl}$ at the area below the largest dunes in the west (Fig. 2). Groundwater level rises up to a maximum height of 2 masl (Tronicke et al., 1999). The appropriate resulting maximum depth of the freshwater-saltwater interface of $80 \mathrm{~m}$ according to Herzberg (1901) is prohibited by the clay layer.

\section{Materials and methods}

\subsection{Instrumentation, sampling and analyses}

Six production wells and a waterworks facility ensure the selfsustaining water supply on Spiekeroog, with only two wells working simultaneously. Wells are pumped at rather low rates of $10 \mathrm{~m}^{3} /$ $\mathrm{h}$ in order to prevent upconing of saline water. The waterworks facility and wells are located in the dune arc to the north of the village (Fig. 2). They are surrounded by seven piezometer nests, each consisting of three individual wells screened in different depths. The screens of the production wells and shallow observation wells (A) are located between $6 \mathrm{mbsl}$ and $19.5 \mathrm{mbsl}$, followed by the observation wells $B$, which are located at depths between $31.5 \mathrm{mbsl}$ and $48 \mathrm{mbsl}$. The deepest screens are the observations wells $C$ located between $52 \mathrm{mbsl}$ and $76 \mathrm{mbsl}$. Except for observation well $25 \mathrm{~B}$ (screen length $=10 \mathrm{~m}$ ), all observation wells have a screen length of $2 \mathrm{~m}$ and all production wells a screen length of $5 \mathrm{~m}$.

During two field campaigns in May and July 2011 samples were taken from production and observation wells as well as from several surface water locations (ponds, dikes and dune slacks) and two seawater locations (Fig. 2). In addition, four rain water samples were collected by a bulk rain collector for the months July-October 2011, thus each sample representing a monthly average. To prevent evaporation, medicinal paraffin oil was placed in the rain collector. It floated over the water with a thickness of about $0.5 \mathrm{~cm}$ following the technical procedure for sampling provided by IAEA (2011). Sampling in the field included measurements of electric conductivity (EC), redox-potential (Eh), $\mathrm{pH}$, temperature and dissolved oxygen concentration using a Hach HQ 40d multi device. In order to avoid atmospheric contact of groundwater, a flow-through cell was used. Three filtered samples were taken for major ion and stable isotope analyses in $50 \mathrm{ml}$ polyethylene bottles, using $0.45 \mu \mathrm{m}$ membrane filters. Cation samples were preserved with nitric acid (65\%) immediately after sampling. All samples were stored in a refrigerator box.

For analysing major cation concentrations, flame atomic absorption spectrometry (AAS) was used according to DIN EN ISO 10304-2. Major anion analyses were carried out by ion chromatography (883 ICplus) according to DIN 38406 . Both sampling campaigns were combined to one data set by averaging the measured values and concentrations. Due to dry weather conditions it was not possible to sample all surface water sampling points twice. Samples with an ion charge balance error $>5 \%$ were discarded except for precipitation samples, which show larger errors due to their very low solute concentrations.

Samples for ${ }^{3} \mathrm{H}-{ }^{3} \mathrm{He}$ dating were collected in July 2011 from nine observation wells at different depths (Table 1 ). Water for tritium $\left({ }^{3} \mathrm{H}\right)$ analysis was stored in polyethylene bottles. Water for helium $\left({ }^{3} \mathrm{He}\right)$ isotope analysis was flushed through a copper tube with a volume of $40 \mathrm{ml}$. To assure a void-free fill, a transparent tube was attached at the inlet of the copper tube and controlled while sampling. A necking at the outlet of the copper tube allowed regulation of the flow rate and thus an increase of pressure in order to avoid potential degassing. The copper tube was then pinched off at both sides for storage. Subsequent analysis of the samples was done at the Institute of Environmental Physics, University of Bremen. Analytical uncertainty is $\pm 3 \%$ or \pm 0.025 TU. Details on the ${ }^{3} \mathrm{H}$ and He isotope analysis are given in Sültenfuß et al. (2009). 


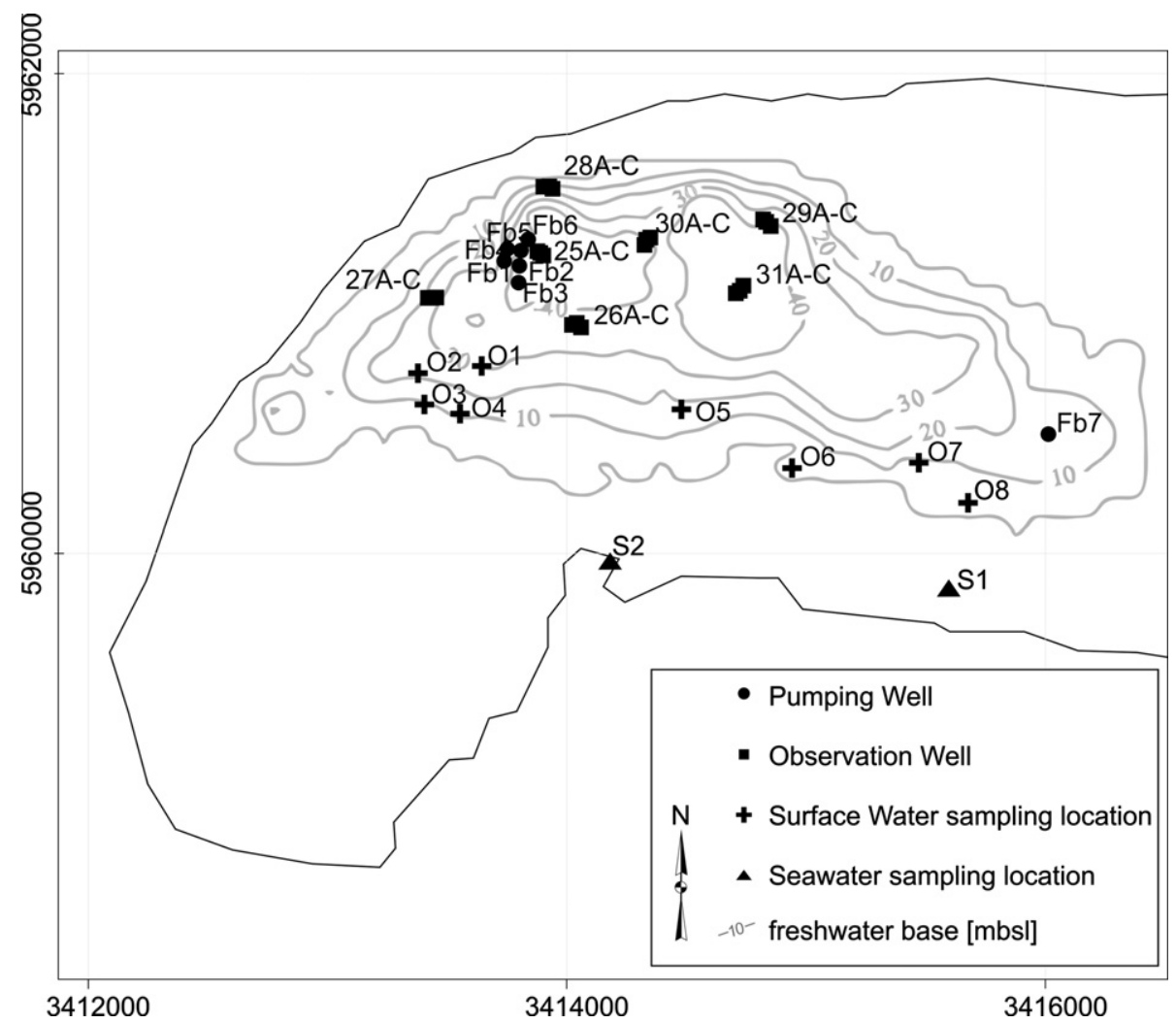

Fig. 2. Map of the western part of Spiekeroog including sampling locations and contour lines of the freshwater base [mbsl] after Tronicke (1997).

Stable water isotopes $\left(\delta^{18} \mathrm{O}\right.$ and $\left.\delta \mathrm{D}\right)$ were determined by a Finnigan MAT-Delta-S mass-spectrometer at the Alfred-Wegener Institute in Potsdam. It is equipped with two equilibration units for the online determination of hydrogen and oxygen isotopic composition. Analytical uncertainty is $\pm 0.1 \%$ for $\delta^{18} \mathrm{O}$ and $\pm 0.8 \%$ for $\delta \mathrm{D}$ measurements, respectively. Details on the method are presented in Meyer et al. (2000).

\subsection{Age dating with ${ }^{3} \mathrm{H}^{3} \mathrm{He}$}

In the late 1950s and early 1960s radioactive hydrogen, tritium $\left({ }^{3} \mathrm{H}\right)$, was released into the atmosphere in large quantities by atmospheric thermonuclear tests (e.g. Solomon and Cook, 2000 and references therein). ${ }^{3} \mathrm{H}$ is incorporated into water molecules and precipitation leads to a deposition of tritium from the troposphere into surface water, groundwater and the biosphere. Tritium has a half-life of 12.32 years and decays to the light helium isotope ${ }^{3} \mathrm{He}$. As soon as gas exchange of water with the atmosphere is inhibited, i.e. after infiltration, the decay product of tritium, tritiogenic ${ }^{3} \mathrm{He}$, accumulates in the water. The relation between the ${ }^{3} \mathrm{H}$ and ${ }^{3} \mathrm{He}$ concentrations gives a time parameter, which is independent of ${ }^{3} \mathrm{H}$ input concentrations and seasonal or regional variations (Eq. (1)). The method to date groundwater by combined measurements of both ${ }^{3} \mathrm{H}$ and ${ }^{3} \mathrm{He}$ was first introduced by Tolstikhin and Kamenskij (1969) and ages are generally referred to as apparent ${ }^{3} \mathrm{H}-{ }^{3} \mathrm{He}$ ages.

$\tau=\frac{1}{\lambda} \cdot \ln \left(1+\frac{{ }^{3} \mathrm{He}_{\text {trit }}}{{ }^{3} \mathrm{H}}\right)$,

with $\tau={ }^{3} \mathrm{H}-{ }^{3} \mathrm{He}$ age, ${ }^{3} \mathrm{He}_{\text {trit }}=$ tritiogenic ${ }^{3} \mathrm{He}, \lambda=0.05626 \mathrm{~s}^{-1}$ (decay constant). The time parameter $\tau$ gives the ${ }^{3} \mathrm{H}-{ }^{3} \mathrm{He}$ age and is assumed to be similar to the groundwater age, which is the time difference between sampling and the last contact of the water with the atmosphere.
To apply this dating method, ${ }^{3} \mathrm{He}_{\text {trit }}$ must be separated from other ${ }^{3} \mathrm{He}$ sources. One source is due to exchange of dissolved gases in the water with the atmosphere. This can be quantified by determination of the solubility equilibrium conditions $\left(\mathrm{He}_{\text {equi }}\right)$ and measuring additional dissolved air generated at infiltration conditions by the excess of $\mathrm{Ne}$ in water, because $\mathrm{Ne}$ has no sources in the subsurface. In principle a small ${ }^{3} \mathrm{He}$ contribution could be produced by the nucleogenic process ${ }^{6} \mathrm{Li}(n, \alpha){ }^{3} \mathrm{H} \rightarrow{ }^{3} \mathrm{He}$ in the subsurface, called ${ }^{3} \mathrm{He}_{\text {terr }} .{ }^{4} \mathrm{He}$ from uranium and thorium decay series is released from the earth crust and can be used additionally as a qualitative time marker (Solomon and Cook, 2000). The so called terrigenic ${ }^{3} \mathrm{He}-{ }^{4} \mathrm{He}$ ratio is nearly $2 \times 10^{-8}$, about two orders of magnitude lower than the atmospheric ${ }^{3} \mathrm{He}-{ }^{4} \mathrm{He}$ ratio, which is $1.384 \times 10^{-6}$. Primordial $\mathrm{He}$ from the mantle $\left(\mathrm{He}_{\text {mantle }}\right)$ could be released in volcanic active zones. Details on the determination of these parameters are given by e.g. Solomon and Cook (2000) and Kipfer et al. (2002).

\subsection{Stable Isotope conventions and corrections}

The composition of oxygen and hydrogen isotopes are given in $\delta$-notation relative to V-SMOW (Vienna standard mean ocean water) expressed in permil as stated in:

$\delta=\left(\frac{R_{\text {sample }}}{R_{\text {Standard }}}-1\right) \cdot 1000$

where $R_{\text {sample }}$ and $R_{\text {Standard }}$ are the isotopic ratios of the sample and the standard.

Due to preferential binding of either heavy or light water molecules in hydration spheres of ions and due to changes in bulk water structure as a consequence of the addition of salts, a socalled isotope salt effect can be observed in saline aqueous solutions (Horita et al., 1993). This effect on the isotopic fractionation of oxygen and hydrogen was determined for the equilibration technique (Bourg et al., 2001) and revised for the AWI instrumentation 
Table 1

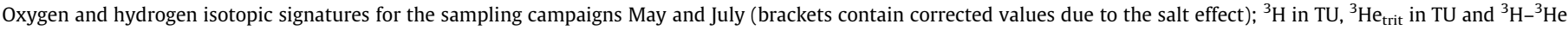
ages in years [yr] for nine samples and oxygen and hydrogen isotopic signatures for monthly averaged precipitation samples from July to October.

\begin{tabular}{|c|c|c|c|c|c|c|c|c|}
\hline \multirow[t]{2}{*}{ Sample } & \multirow[t]{2}{*}{ Sample type } & \multicolumn{2}{|l|}{ May } & \multicolumn{5}{|l|}{ July } \\
\hline & & $\begin{array}{l}\delta^{18} \mathrm{O} \\
\left(\delta^{18} \mathrm{O}_{\text {corr }}\right) \\
\% \text { vo. V-SMOW }\end{array}$ & $\begin{array}{l}\delta \mathrm{D} \\
\left(\delta \mathrm{D}_{\text {corr }}\right) \\
\% \text { vs. V-SMOW }\end{array}$ & $\begin{array}{l}\delta^{18} \mathrm{O} \\
\left(\delta^{18} \mathrm{O}_{\text {corr }}\right) \\
\% \text { vs. V-SMOW }\end{array}$ & $\begin{array}{l}\delta \mathrm{D} \\
\left(\delta \mathrm{D}_{\text {corr }}\right) \\
\% \text { vs. V-SMOW }\end{array}$ & $\begin{array}{l}{ }^{3} \mathrm{H} \\
\mathrm{TU}\end{array}$ & $\begin{array}{l}{ }^{3} \mathrm{He}_{\text {trit }} \\
\mathrm{TU}\end{array}$ & $\begin{array}{l}{ }^{3} \mathrm{H}-{ }^{3} \mathrm{He} \text { age } \\
\mathrm{yr}\end{array}$ \\
\hline FB1 & Product. well & -7.18 & -48.25 & -7.22 & -48.62 & & & \\
\hline FB2 & Product. well & -7.07 & -47.79 & -7.12 & -47.36 & & & \\
\hline FB3 & Product. well & -7.08 & -48.23 & -7.18 & -47.75 & & & \\
\hline FB4 & Product. well & -7.03 & -48.37 & -7.19 & -47.33 & & & \\
\hline FB5 & Product. well & -7.11 & -48.38 & -7.10 & -48.69 & & & \\
\hline FB6 & Product. well & -7.06 & -47.37 & -7.17 & -48.90 & & & \\
\hline FB7 & Product. well & -7.19 & -47.39 & $\mathrm{n} / \mathrm{a}$ & $\mathrm{n} / \mathrm{a}$ & & & \\
\hline $25 \mathrm{~A}$ & Shallow obs. well & -6.98 & -45.77 & -6.98 & -46.22 & & & \\
\hline $26 \mathrm{~A}$ & Shallow obs. well & -6.98 & -47.22 & -6.99 & -46.40 & & & \\
\hline $27 \mathrm{~A}$ & Shallow obs. well & -7.22 & -48.65 & -7.28 & -47.25 & 7.3 & 21.8 & 25 \\
\hline $28 \mathrm{~A}$ & Shallow obs. well & -6.99 & -46.08 & -6.97 & -46.47 & & & \\
\hline $29 A$ & Shallow obs. well & -6.75 & -43.30 & -6.81 & -43.81 & 9.8 & 6.0 & 8.5 \\
\hline $30 \mathrm{~A}$ & Shallow obs. well & -6.50 & -42.93 & -6.63 & -43.69 & 9.9 & 2.8 & 4.4 \\
\hline $31 \mathrm{~A}$ & Shallow obs. well & -7.25 & -47.47 & -7.28 & -47.49 & & & \\
\hline $25 B$ & Medium obs. well & -7.14 & -49.45 & -7.16 & -48.65 & & & \\
\hline $26 B$ & Medium obs. well & -7.24 & -50.05 & -7.26 & -49.00 & & & \\
\hline $27 \mathrm{~B}$ & Medium obs. well & -7.28 & -49.82 & -7.21 & -50.29 & 8.4 & 68.7 & 39 \\
\hline $28 \mathrm{~B}$ & Medium obs. well & -7.30 & -49.36 & -7.31 & -49.26 & & & \\
\hline $29 B$ & Medium obs. well & -7.45 & -50.31 & -7.40 & -50.22 & 11.1 & 111.3 & 43 \\
\hline $30 \mathrm{~B}$ & Medium obs. well & -7.47 & -50.25 & -7.39 & -50.15 & 8.7 & 62.0 & 37 \\
\hline 31B & Medium obs. well & -7.25 & -49.60 & -7.31 & -49.19 & & & \\
\hline $25 \mathrm{C}$ & Deep obs. well & $\begin{array}{l}-2.29 \\
(-2.27)\end{array}$ & $\begin{array}{l}-15.30 \\
(-14.55)\end{array}$ & $\begin{array}{l}-2.22 \\
(-2.20)\end{array}$ & $\begin{array}{l}-14.70 \\
(-13.95)\end{array}$ & & & \\
\hline $26 C$ & Deep obs. well & $\begin{array}{l}-2.83 \\
(-2.81)\end{array}$ & $\begin{array}{l}-18.90 \\
(-18.13)\end{array}$ & $\begin{array}{l}-2.76 \\
(-2.74)\end{array}$ & $\begin{array}{l}-18.93 \\
(-18.16)\end{array}$ & & & \\
\hline $27 C$ & Deep obs. well & -6.65 & -45.78 & -6.70 & -45.84 & 0.02 & 0.9 & $>70$ \\
\hline $28 \mathrm{C}$ & Deep obs. well & $\begin{array}{l}-2.67 \\
(-2.65)\end{array}$ & $\begin{array}{l}-18.18 \\
(-17.45)\end{array}$ & $\begin{array}{l}-2.59 \\
(-2.57)\end{array}$ & $\begin{array}{l}-18.10 \\
(-17.29)\end{array}$ & & & \\
\hline $29 C$ & Deep obs. well & $\begin{array}{l}-2.46 \\
(-2.43)\end{array}$ & $\begin{array}{l}-16.34 \\
(-15.38)\end{array}$ & $\begin{array}{l}-2.42 \\
(-2.39)\end{array}$ & $\begin{array}{l}-16.35 \\
(-15.40)\end{array}$ & 0.00 & 5.7 & $>70$ \\
\hline $30 \mathrm{C}$ & Deep obs. well & $\begin{array}{l}-2.87 \\
(-2.84)\end{array}$ & $\begin{array}{l}-19.32 \\
(-18.41)\end{array}$ & $\begin{array}{l}-2.77 \\
(-2.74)\end{array}$ & $\begin{array}{l}-19.06 \\
(-18.15)\end{array}$ & 0.00 & 2.4 & $>70$ \\
\hline $31 C$ & Deep obs. well & $\begin{array}{l}-3.09 \\
(-3.06)\end{array}$ & $\begin{array}{l}-20.54 \\
(-19.46)\end{array}$ & $\begin{array}{l}-3.00 \\
(-2.97)\end{array}$ & $\begin{array}{l}-20.76 \\
(-19.67)\end{array}$ & & & \\
\hline 01 & Surface water & -6.84 & -47.43 & -6.92 & -46.90 & & & \\
\hline $\mathrm{O} 2$ & Surface water & -2.71 & -24.89 & -0.03 & -12.60 & & & \\
\hline $\mathrm{O} 3$ & Surface water & -5.20 & -35.63 & -5.14 & -32.90 & & & \\
\hline $\mathrm{O} 4$ & Surface water & -4.13 & -28.23 & -5.27 & -36.80 & & & \\
\hline O5 & Surface water & $\mathrm{n} / \mathrm{a}$ & $\mathrm{n} / \mathrm{a}$ & -6.28 & -42.70 & & & \\
\hline 06 & Surface water & $\mathrm{n} / \mathrm{a}$ & $\mathrm{n} / \mathrm{a}$ & -2.97 & -28.03 & & & \\
\hline 07 & Surface water & $\begin{array}{l}-2.44 \\
(-2.43)\end{array}$ & $\begin{array}{l}-21.32 \\
(-21.19)\end{array}$ & $\begin{array}{l}-3.23 \\
(-3.23)\end{array}$ & $\begin{array}{l}-26.57 \\
(-26.50)\end{array}$ & & & \\
\hline 08 & Surface water & $\mathrm{n} / \mathrm{a}$ & $\mathrm{n} / \mathrm{a}$ & -3.44 & -29.99 & & & \\
\hline $\mathrm{S} 1$ & Seawater & $\begin{array}{l}-0.79 \\
(-0.76)\end{array}$ & $\begin{array}{l}-5.22 \\
(-4.26)\end{array}$ & $\mathrm{n} / \mathrm{a}$ & $\mathrm{n} / \mathrm{a}$ & & & \\
\hline S2 & Seawater & $\mathrm{n} / \mathrm{a}$ & $\mathrm{n} / \mathrm{a}$ & $\begin{array}{l}-0.48 \\
(-0.45)\end{array}$ & $\begin{array}{l}-4.62 \\
(-3.63)\end{array}$ & & & \\
\hline N7 & Prec. & -5.73 & -38.40 & & & & & \\
\hline N8 & Prec. & -5.57 & -37.70 & & & & & \\
\hline N9 & Prec. & -6.30 & -42.30 & & & & & \\
\hline N10 & Prec. & -5.85 & -35.40 & & & & & \\
\hline
\end{tabular}

on the basis of synthetic solutions of $\mathrm{Na}-\mathrm{Cl}$ (Kohfahl et al., 2008). The curve progresses nearly linear. The isotope salt effect of the samples was corrected as:

$\delta^{18} \mathrm{O}_{\text {corr }}=\delta^{18} \mathrm{O}_{\text {measured }}+(0.072 \cdot c(\mathrm{NaCl}))$

$\delta D_{\text {corr }}=\delta D_{\text {measured }}+(2.278 \cdot c(\mathrm{NaCl}))$

where $c$ is the concentration in $\mathrm{mol} / \mathrm{l}$ (Kohfahl et al., 2008). This was taken into account for calculating the results of samples with electric conductivities exceeding $5 \mathrm{mS} / \mathrm{cm}$ (Table 1). For samples with electric conductivities less than $5 \mathrm{mS} / \mathrm{cm}$, corrections lie within the measurement error. Assuming that dynamics are relatively low and changes in concentrations of $\mathrm{Na}^{+}$and $\mathrm{Cl}^{-}$within 1 month are negligible, the $\mathrm{Na}-\mathrm{Cl}$ concentrations for the correction of the deep observation wells $C$ were taken from those sampling campaigns where the electrical charge balance was best.
Additionally, a local meteoric waterline (LMWL) is shown in order to compare the isotopic data with regional data of stable isotopes in precipitation. The closest location to Spiekeroog with an IAEA LMWL available is Cuxhaven (IAEA, 2011). It averages monthly precipitation data from 1978 to 2005 and follows a LMWL of:

$\delta D=7.79 \cdot \delta^{18} \mathrm{O}+5.15$

\section{Results}

\subsection{Apparent ${ }^{3} \mathrm{H}-{ }^{3} \mathrm{He}$ ages}

Concentrations of ${ }^{3} \mathrm{H},{ }^{3} \mathrm{He}_{\text {trit, }}$, and apparent groundwater ages are plotted against the mean screen depth [mbsl] in Fig. 3. In addition, the clay layer is drawn schematically into each plot. For 
reasons of simplification, the clay layer is here assumed to be continuous and its thickness is averaged to $5 \mathrm{~m}$. Above the clay layer, ${ }^{3} \mathrm{H}$ and ${ }^{3} \mathrm{He}_{\text {trit }}$ concentrations of shallow (observation wells A) and medium (observation wells B) wells increase with depth. Sample $29 \mathrm{~B}$ at medium depth shows the highest ${ }^{3} \mathrm{H}$ and ${ }^{3} \mathrm{He}_{\text {trit }}$ concentrations. The corresponding groundwater ages increase with depth as expected. Shallow groundwater samples have an apparent ${ }^{3} \mathrm{H}-{ }^{3} \mathrm{He}-$ age between 4.4 and 25 years. Groundwater at medium depth shows apparent ${ }^{3} \mathrm{H}-{ }^{3} \mathrm{He}$-ages between 37 and 43 years.

The deep observation wells (C) show ${ }^{3} \mathrm{H}$ concentrations less than 0.025 TU. Assuming a concentration of natural tritium in precipitation for the North Sea region of at least $4 \mathrm{TU}$ (continental Europe 5 TU, Roether, 1967), these samples must be older than 70 years.

In Fig. 4, the sum of measured ${ }^{3} \mathrm{H}+{ }^{3} \mathrm{He}_{\text {trit }}$ concentrations (hereafter called 'initial tritium') of the shallow and medium observation well samples are plotted against their calculated infiltration points in time. Also shown are monthly mean tritium concentrations in precipitation for Groningen (1970-2007), for Cuxhaven (1978-2007) and for Ottawa (1953-2007)(IAEA, 2011). The Ottawa precipitation data clearly indicates the concentration maximum in the 1960s as a consequence of the thermonuclear tests.

The maximum initial tritium concentration of $122 \mathrm{TU}$ is assigned to an infiltration in 1968. Concentrations decrease for younger samples thereafter to $12.7 \mathrm{TU}$. Initial tritium concentrations of the shallow samples match ${ }^{3} \mathrm{H}$ concentrations in precipitation for Groningen and Cuxhaven. For these shallow samples mixing with tritium-free water can be excluded. As the oldest medium sample shows initial tritium of about $30 \%$ less than the precipitation data, this sample contains a small portion of older water from the pre-bomb period. For the other two medium samples (27B and 30B) the old pre-bomb portion is not significant.

\subsection{Stable Isotopes}

Fig. 5 is a scatter plot of $\delta \mathrm{D}$ vs. $\delta^{18} \mathrm{O}$ for all samples and longterm monthly precipitation data of Cuxhaven. Monthly averaged oxygen isotope signatures for the precipitation of Cuxhaven from 1978 to 2005 range between $-8.31 \%$ (December) and $-5.90 \%$ (July). The monthly isotopic precipitation data for Spiekeroog includes July, August, September and October. It shows less negative isotope signatures compared to Cuxhaven (Fig. 5). This may, however, be caused by the fact that the monthly precipitation data of Spiekeroog includes only samples from 1 year, whereas the Cuxhaven precipitation data is averaged over 27 years.

Seawater, surface water, fresh and saline groundwater all plot at different locations on the diagrams. The two North Sea samples show $\delta^{18} \mathrm{O}$ signatures of $-0.76 \%$ and $-0.45 \%$. These slightly negative $\delta^{18} \mathrm{O}$ values with regard to $\mathrm{V}$-SMOW likely reflect mainly the isotopic signature of seawater with a limited admixture of freshwater.

Groundwater samples from production wells, observation wells A and observation wells B show a lighter isotopic composition compared to seawater. Their isotopic signatures lie in a narrow range between $-6.50 \%$ and $-7.47 \%$ or for $\delta^{18} \mathrm{O}$, reflecting average annual precipitation signatures. A general increase in light isotopes is observed from shallow groundwater samples over samples of the production wells to samples of the observation wells $B$. This can also be seen in Fig. 6 , where $\delta^{18} \mathrm{O}$ of all samples are plotted against the mean screen depth.

For the deep observation wells in Figs. 5 and 6, significantly different isotopic signatures are observed. Except for one (27C), which is screened above the clay layer (Fig. 6), all samples are considerably heavier (i.e. less negative) than the remaining fresh groundwater samples and show isotopic signatures from $-2.20 \%$ to $-3.06 \%$ for $\delta^{18} \mathrm{O}$ and $-13.95 \%$ to $-19.67 \%$ for $\delta \mathrm{D}$. These seawater samples also vary from V-SMOW. The correction for the salt effect does hardly show an impact on the isotopic compositions (compare Table 1).

The surface water isotopic signatures show a large variation, depending on the sampling location. While some samples display heavier isotopic composition with evaporation characteristics, others plot in between the shallow groundwater wells and the summer precipitation data of Spiekeroog, indicating two-component mixing.

\subsection{Hydrochemistry}

All major ion data is plotted in a Piper plot in Fig. 7. In general, two main groups can be differentiated, indicated by a gray background color. The group on the right represents $\mathrm{Na}-\mathrm{Cl}$-waters and includes precipitation, seawater and deep groundwater samples (observation wells $\mathrm{C}$ ).

A broader range of water types can be found in the group to the left. Samples from the shallow observation wells (A) are classified as $\mathrm{Ca}-\mathrm{Na}-\mathrm{HCO}_{3}-\mathrm{Cl}$-water. Samples of production wells and medium observations wells (B) have higher magnesium and lower calcium concentrations and are therefore $\mathrm{Na}-\mathrm{Ca}-\mathrm{Mg}-\mathrm{HCO}_{3}-\mathrm{Cl}-$ waters. The majority of the surface water samples can be described as $\mathrm{Na}-\mathrm{Ca}-\mathrm{HCO}_{3}-\mathrm{Cl}$-waters. Besides, two observation well samples (26A, 25B) plot in between these two groups. They are characterized by increasing $\mathrm{Na}-\mathrm{Cl}$ concentrations.

Differences exist between pH values of surface water or shallow groundwater samples with a $\mathrm{pH}$ of 8 and deep groundwater samples with $\mathrm{pH}$ values between 6.3 and 7.5. A slight shift in $\mathrm{pH}$ values in the surface water samples from alkaline $\mathrm{pH}$ values at the salt
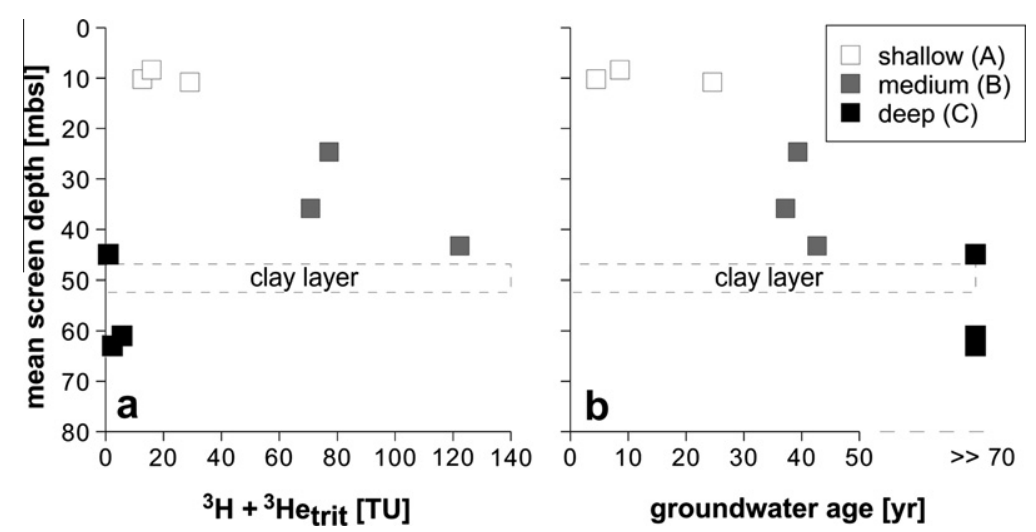

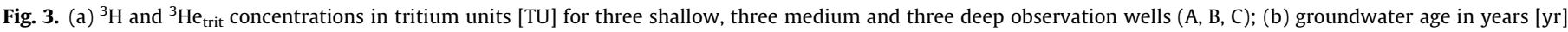
against the mean screen depth [mbsl] for the observation wells 27, 30 and 29; the clay layer is included, simplified and averaged to a thickness of 5 m. 


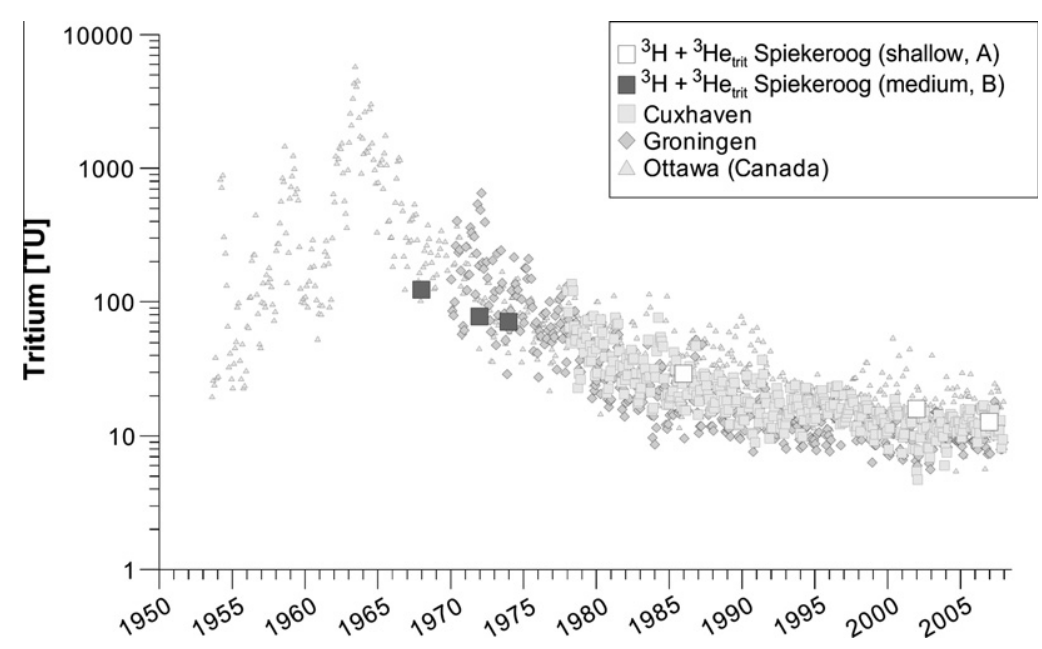

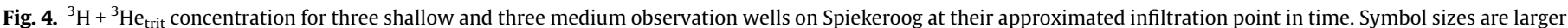

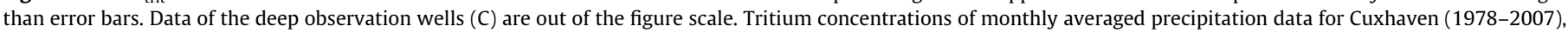
Groningen (1970-2007) and Ottawa (1953-2007)(IAEA, 2011).

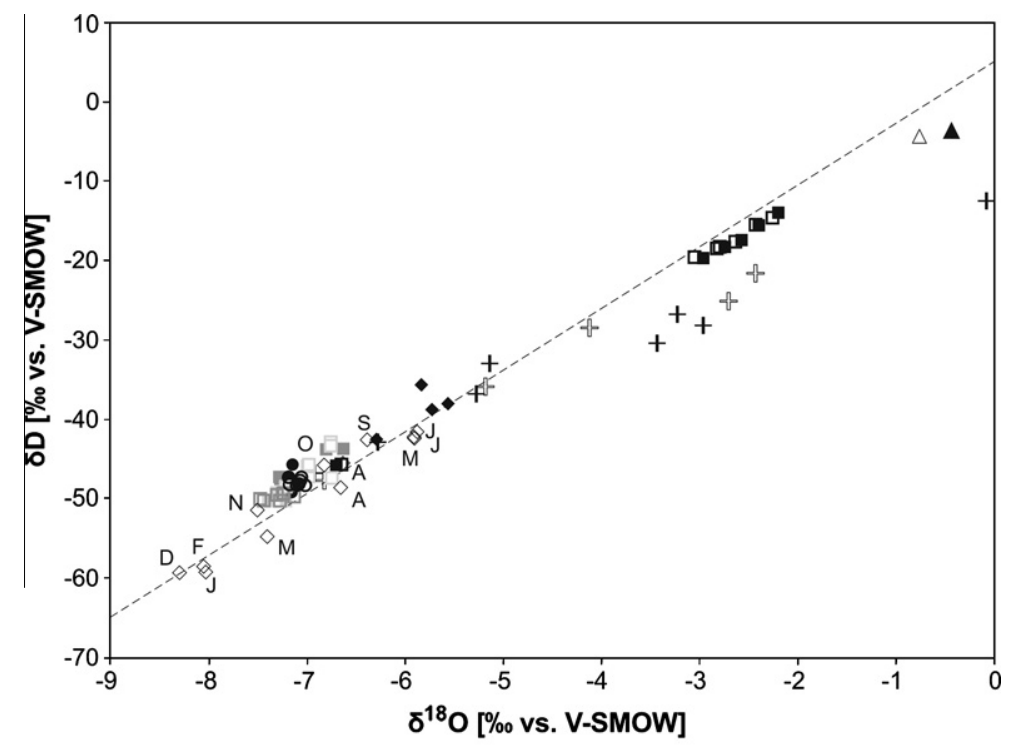

\begin{tabular}{|c|c|c|}
\hline May & $\begin{array}{l}\text { July } \\
\Delta \text { seawater }\end{array}$ & $\begin{array}{l}-- \text { LMWL Cuxhaven } \\
\quad\left(\delta D=7.79^{*} \delta^{18} O+5.15\right)\end{array}$ \\
\hline $\begin{array}{l}+ \\
\circ\end{array}$ & $\begin{array}{l}+ \text { surface water } \\
\text { - } \text { production well }\end{array}$ & $\begin{array}{l}\diamond \text { monthly precipitation data } \\
\text { for Cuxhaven }\end{array}$ \\
\hline & observation wells & $\begin{array}{l}\text { - monthly precipitation data } \\
\text { for Spiekeroog }\end{array}$ \\
\hline ㅁ & " shallow $(A)$ & \\
\hline 口 & - medium $(B)$ & \\
\hline व & - $\quad \operatorname{deep}(\mathrm{C})$ & \\
\hline
\end{tabular}

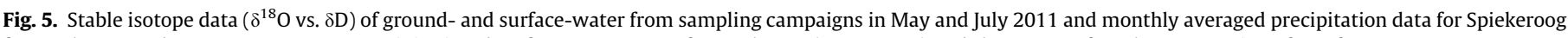
from July to October 2011. Long-term precipitation data from 1978-2005 for Cuxhaven (IAEA, 2011) and the LMWL of Cuxhaven are given for reference.

marsh $(\mathrm{S} 3, \mathrm{~S} 4, \mathrm{~S} 5)$ to more acidic $\mathrm{pH}$ values in the area of the oldest dunes $(04,05)$ occurs.

Almost all freshwater samples show a slight supersaturation with respect to calcite (mean 0.32; STD: 0.25), except for wells $27 \mathrm{~A}$ and $27 \mathrm{~B}$ where the saturation indices were calculated as $\mathrm{SI}_{\mathrm{cal}}$ cite $=-0.11$ and $\mathrm{SI}_{\text {calcite }}=-0.26$, respectively. The saturation indices were computed with the hydrogeochemical reaction model PHREEQC-2 (Parkhurst and Appelo, 1999). Overall, these results suggest that the decalcification front has not yet migrated to greater depths.

\section{Discussion}

\subsection{Groundwater age distribution and recharge patterns}

A schematic cross-section from WSW to ENE through the main dune arc in the western part of Spiekeroog (Fig. 8) gives an overview of the groundwater age distribution. The six samples from the shallow and medium observation wells lie well within the freshwater lens. One sample from the deep observation wells 


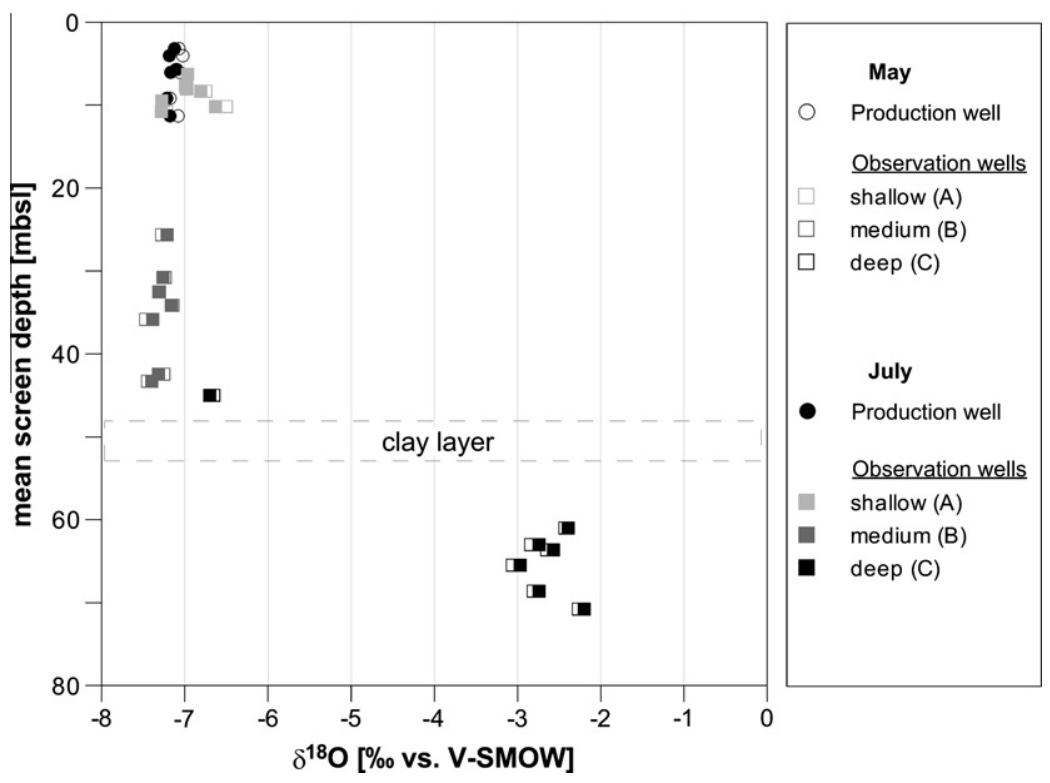

Fig. 6. Oxygen isotope composition in Spiekeroog in May and July 2011. Production and observation wells are plotted against their mean screen depth [mbsl].

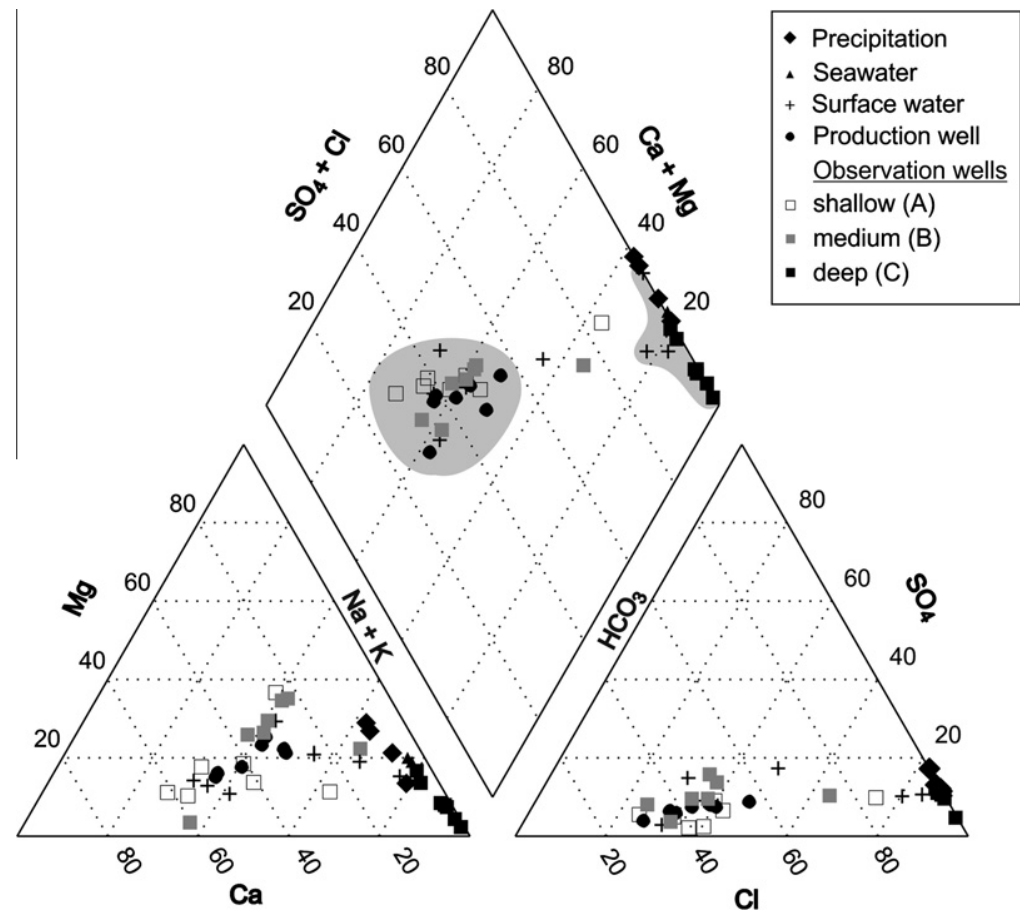

Fig. 7. Piper plot of major ions for precipitation data from July to October, groundwater, surface and seawater samples.

represents the transition zone between freshwater and seawater with an apparent ${ }^{3} \mathrm{H}-{ }^{3} \mathrm{He}$ age of $>70$ years. The remaining deep $\mathrm{C}$ wells were located below the restricting clay layer in seawater and have ages greater than 70 years.

It becomes evident from Fig. 8 that groundwater age increases, as expected, with depth. However, it also increases from the center of the freshwater lens to the discharge boundary. This is not in line with the largely horizontal age stratification expected in an idealized system (homogeneous, isotropic medium and evenly distributed groundwater recharge) for an oceanic strip island (Vacher et al., 1990). This discrepancy may be a result of yet unknown factors, for example an uneven groundwater recharge distribution and/or a notable deviation from a homogeneous/isotropic system.
The central shallow and medium depths samples from observation well 30 display the youngest ages at the respective depths. Approximate groundwater flow paths were derived in Fig. 8 from the observed groundwater age data.

To give an estimation of the average travel time in the freshwater lens, the analytical solution of Vacher et al. (1990) is used as follows:

$\tau_{0}=\left[\frac{(\alpha+1)}{K * R}\right]^{1 / 2} * n * \pi * \frac{L}{8}$

with $K=$ hydraulic conductivity [m/d], $R=$ recharge $[\mathrm{m} / \mathrm{d}], \alpha=$ density relationship between freshwater $\left(1000 \mathrm{~kg} / \mathrm{m}^{3}\right)$ and seawater 


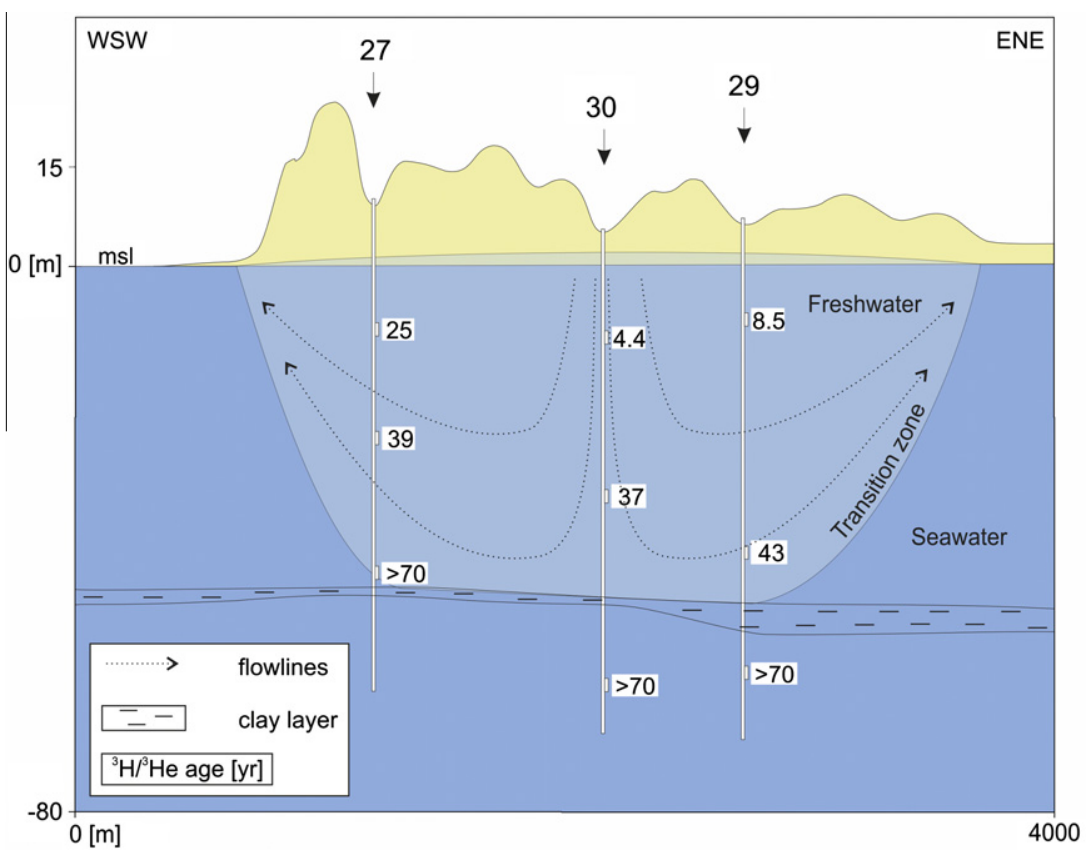

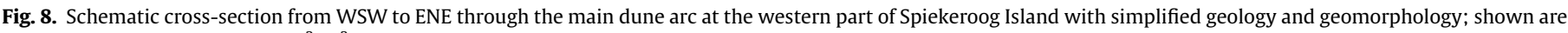

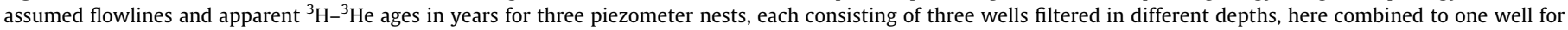
simplification.

$\left(1025 \mathrm{~kg} / \mathrm{m}^{3}\right), n=$ effective porosity and $L=$ width of the island. For a hydraulic conductivity of $1 * 10^{-4} \mathrm{~m} / \mathrm{s}$ (OOWV, 2009), an island width of $1400 \mathrm{~m}$, a density relationship of 40 , an estimated effective porosity of 0.4 and a recharge rate between 300 and $500 \mathrm{~mm} / \mathrm{a}$ (OOWV, 2009) results an average groundwater age between 35 and 46 years. As this analytical solution does not consider an underlying aquitard, these average groundwater travel times are only estimates.

An approximate average recharge rate can be calculated from the apparent ${ }^{3} \mathrm{H}-{ }^{3} \mathrm{He}$ age at well 30 , assuming that the groundwater flow at this location is only in vertical direction (since well 30 is located almost in the center of the main dune arc) and constant with depth. Further an effective porosity of $30-40 \%$ is assumed for dune sand (Vandenbohede and Lebbe, 2005; Stuyfzand, 1993). For the shallow screen (30A) at a depth of $11.7 \mathrm{~m}$ below the groundwater table and with a groundwater age of 4.4 years this results in a recharge rate of $\sim 800-1060 \mathrm{~mm} / \mathrm{a}$. For the screen at medium depth (30B), i.e. at $36.4 \mathrm{~m}$ below the groundwater table and with a groundwater age of 37 years the resulting recharge rate is $\sim 300-400 \mathrm{~mm} / \mathrm{a}$.

The recharge rate calculated from the deeper screen is consistent with the previous estimates of Dörhöfer and Josopait (OOWV, 2009). In contrast, the recharge rate calculated from the shallow screen is extremely high, drastically exceeding the already very high value of $>600 \mathrm{~mm} / \mathrm{a}$ derived from the lysimeter measurements, which is presumably not representative for a larger area.

Possible explanations for these extremely high recharge rates calculated from the shallow screen data are (i) an error in the ${ }^{3} \mathrm{H}$ or ${ }^{3} \mathrm{He}$ analytics, which seems unlikely because every sample was taken and measured twice or (ii) the observation well is leaking at shallow depth leading to this outstanding young groundwater compared to the other shallow groundwater ages.

For more detailed recharge calculations, the strong dependence of evapotranspiration losses on vegetation types in coastal dunes should be taken into account (Stuyfzand, 1993). Large differences occur between the evapotranspiration losses on dune sands or on the areas which are covered with pines.

\subsection{Isotopic characterization and water origin}

A conceptual 3-D model of Spiekeroog with representative oxygen isotopic compositions and electric conductivities is shown in Fig. 9. The seawater isotopic composition nearly corresponds to V-SMOW. $\delta^{18} \mathrm{O}$ values slightly lower than V-SMOW in coastal regions are often explained by river discharge (Clark and Fritz, 1997). In general, a strong influence of river discharge by the rivers Rhine, Meuse and Elbe exists in the southern North Sea (Lenhardt et al., 1997). The immediate area around Spiekeroog is affected by strong ocean currents (Staneva et al., 2008) and a noticeable river discharge from the Ems and Weser is observed (Duinker et al., $1982,1985)$. Thus, isotopic variations in seawater close to Spiekeroog are supposed to result from river inputs. The seawater has an electric conductivity of $\sim 50.000 \mu \mathrm{S} / \mathrm{cm}$, thus lower than under fully marine conditions.

The $\delta^{18} \mathrm{O}$ values of Spiekeroog precipitation are depleted in heavy isotopes compared to seawater, because of isotope fractionation during primary evaporation and condensation (Clark and Fritz, 1997). The $\delta^{18} \mathrm{O}$ precipitation value in Fig. 9 shows the representative annual mean of Cuxhaven $(-6.97 \%)$ and a mean electrical conductivity of $80.5 \mu \mathrm{S} / \mathrm{cm}$ based on the Spiekeroog rainwater samples. For rainwater, this value is rather high, owing to the close proximity of the sea (Appelo and Postma, 2005).

The surface water samples show a large variety of electric conductivities and isotope signatures due to different sampling locations (Fig. 9). Samples within the dune area are characterized by lower electric conductivities with a maximum of $860 \mu \mathrm{S} / \mathrm{cm}$. Other samples were taken on the verge of the salt marsh area and point towards brackish waters with electric conductivities between 1094 and $6880 \mu \mathrm{S} / \mathrm{cm}$. At some locations, the isotopic signatures indicate groundwater origin (e.g. sample 01, compare Table 1). Other samples are strongly influenced by evaporation (compare Fig. 5).

Samples from the medium observation wells show a lighter isotopic composition than those from the shallow wells. More negative isotopic signatures with depth could implicate colder temperature conditions during earlier infiltration and could thus 


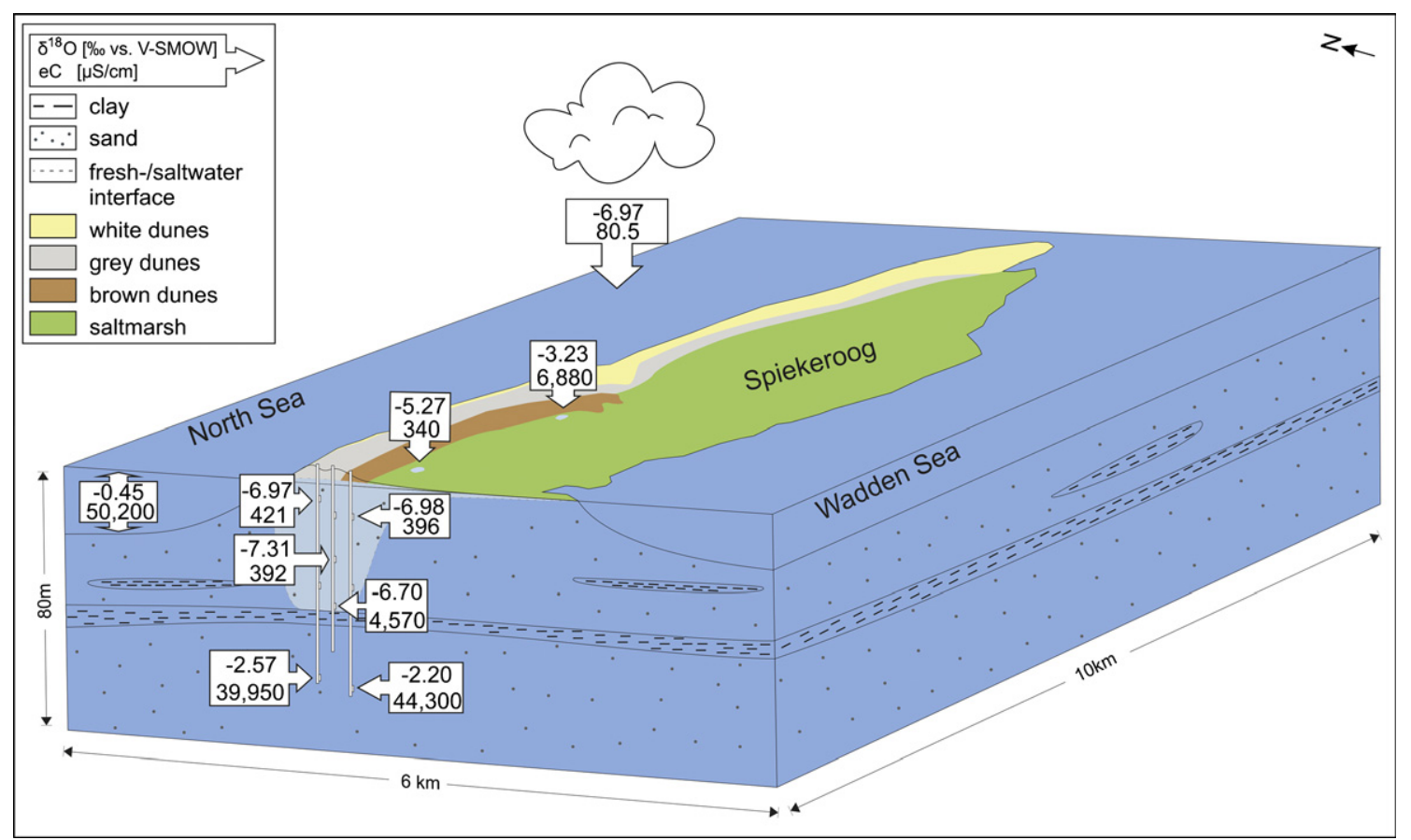

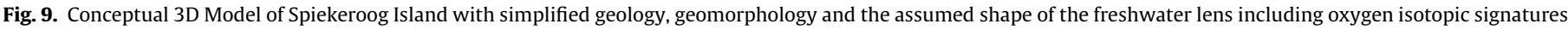
[\%o vs. V-SMOW] and electric conductivities $[\mu \mathrm{S} / \mathrm{cm}]$.

be an indicator for a shift towards changed recharge patterns or a general temperature increase. Moreover, this could match with the warming trend in temperature for central Europe (Christensen et al., 2007) and a sea surface temperature increase of the North Sea in the last 15 years (Mackenzie and Schiedek, 2007). However, the amount of available data is low and restricts the significance.

At a short distance above the clay layer, the sudden increase of electric conductivity $(4.570 \mu \mathrm{S} / \mathrm{cm})$ and less negative oxygen isotopic signatures mark the transition zone between freshwater and seawater.

Saltwater below the freshwater lens is represented by samples from deep observation wells (Fig. 9). They show relatively heavy oxygen isotopic compositions and high electric conductivities. However, they differentiate from the before-mentioned values for seawater at the surface (compare also chapter 4.2). The electric conductivities, i.e. salinities, lie in between the normal range for the coastal areas of the North Sea within the last 800 years (Scheurle and Hebbeln, 2003; Scheurle et al., 2005). Oxygen isotopic composition in the North Sea varies, however, typically between $-0.6 \%$ and $+0.6 \%$ (Harwood et al., 2008). An explanation for the more negative oxygen isotopic signatures of -2.20 to $-3.06 \%$ could be a small influence of freshwater from the above lying freshwater reservoir. The approximate freshwater fraction in the saltwater is calculated with the chloride concentrations and electrical conductivites in the following chapter.

\subsection{Hydrochemical evolution from recharge to discharge}

The hydrochemical results provide information on the water evolution along different flow paths through the freshwater lens. As shown by stiff diagrams of representative samples in Fig. 10, significant differences exist in major ion concentrations between precipitation, shallow, medium and deep groundwater (compare Table 2).

Typical for coastal precipitation is the dominance of $\mathrm{Na}-\mathrm{Cl}$ as shown in Fig. 10. In order to identify the seawater fraction in rainwater, sea- and rainwater are compared by using chloride. Chloride shows little fractionation between seawater and rainwater and is therefore used as inert reference component (Appelo and Postma, 2005). According to Appelo and Postma, the net effect of the $\mathrm{Na}^{+} / \mathrm{Cl}^{-}$ratio remains the same either in rainwater or seawater, which allows a comparison as follows:

$F_{\mathrm{Na}^{+}}=\frac{(\mathrm{Cl} / \mathrm{Na})_{\text {rain }}}{(\mathrm{Cl} / \mathrm{Na})_{\text {seaw }}}$

with $\mathrm{F}_{\mathrm{Na}^{+}}=$fractionation factor (Appelo and Postma, 2005). Taking into account the seawater concentration of $\mathrm{Na}^{+}=485 \mathrm{mmol} / \mathrm{l}$ and $\mathrm{Cl}^{-}=566 \mathrm{mmol} / \mathrm{l}$ leads to a ratio of 0.86 (Appelo and Postma, 2005). In the precipitation of Spiekeroog, the average $\mathrm{Cl}^{-}$concentration is $0.52 \mathrm{mmol} / \mathrm{l}$. The $\mathrm{Na}^{+}$fraction derived from seawater is therefore $0.52 \times 0.86=0.45 \mathrm{mmol} / \mathrm{l}$. Considering the analytical accuracy, the difference of $0.073 \mathrm{mmol} / 1$ is hardly significant. It follows, that most of the precipitation has a marine origin, as expected due to the proximity to the ocean.

Moreover, a comparison of chloride concentration in the precipitation with the groundwater concentration in shallow depths (production wells and observation wells A) gives information on the amount of evaporation losses. The mean chloride concentration in precipitation is $18 \mathrm{mg} / \mathrm{l}$. This results in a fraction of $28 \%$ in the shallow groundwater $(65 \mathrm{mg} / \mathrm{l}$, excluding $26 \mathrm{~A})$. The remaining fraction of $72 \%$ is supposed to result from enrichment due to evaporation. The fraction $(y)$ of evapotranspiration losses in the annual precipitation amount can be calculated as:

$y=-x *\left(\frac{c_{0}}{c_{1}}-1\right)$

with $c_{0}=$ mean concentration in precipitation $[\mathrm{mg} / \mathrm{l}], c_{1}=$ mean concentration in shallow observation wells (A) and production wells [mg/l], $x=$ annual precipitation average [mm/a]. The resulting amount of annual evapotranspiration is about $540 \mathrm{~mm}$. This implies a groundwater recharge rate of $210 \mathrm{~mm} / \mathrm{a}$, which is consistent with the groundwater recharge model Growa06V2 for the area of Spiekeroog (NIBIS Kartenserver, 2011) and with recharge rates of the Frisian Islands (Beukeboom, 1976). Additionally, it must be 


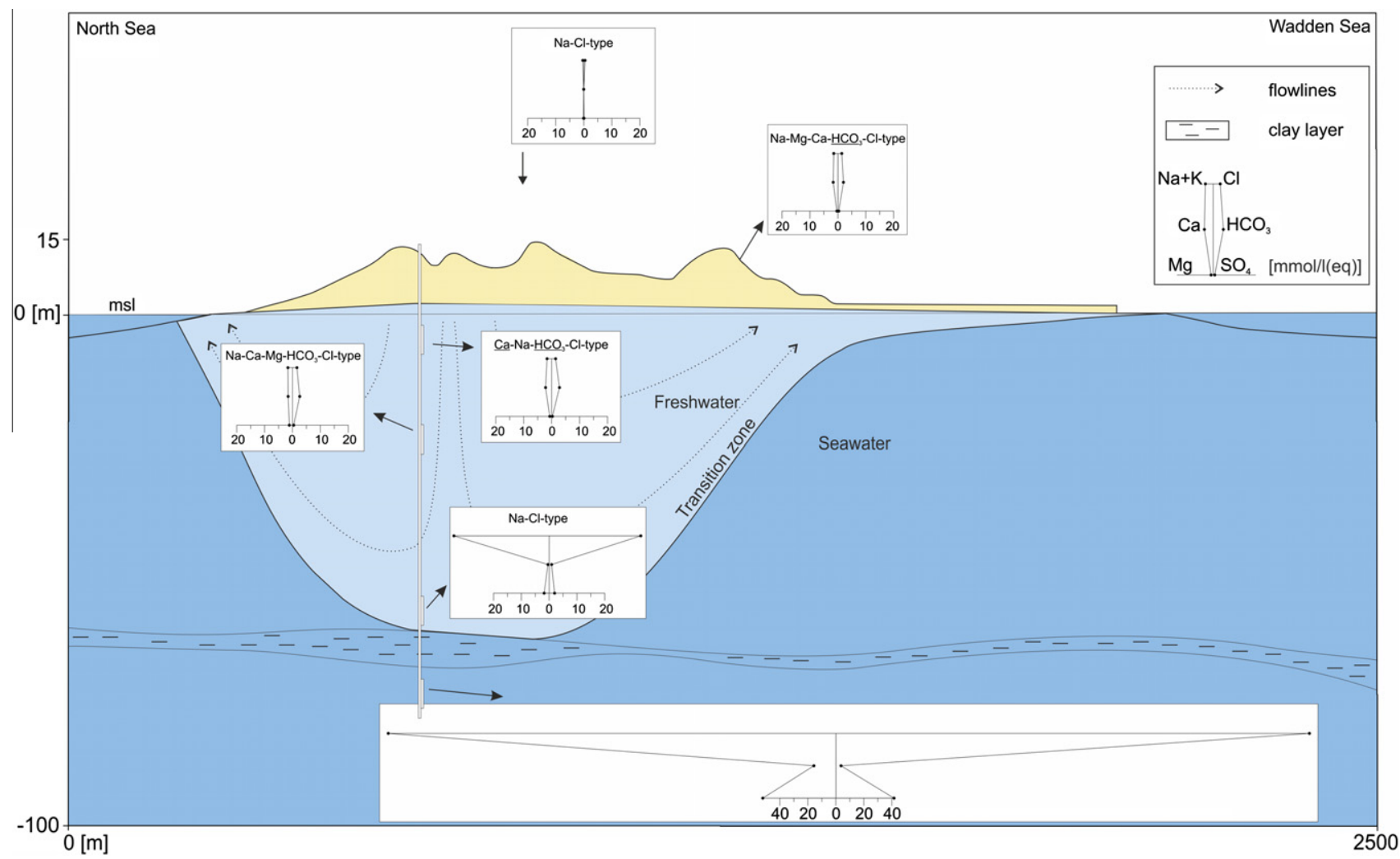

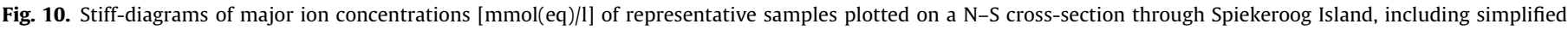
geology and geomorphology and the assumed shape of and flow lines in the freshwater lens.

considered that $c_{0}$ is here based on only four data points and the average chloride concentration in precipitation for the Dutch coast is even lower (Appelo and Postma, 2005). This would lead to even higher evapotranspiration losses. On the other hand, this simple assumption does not consider the impact of sea spray on the sodium and chloride concentration, which is significant according to Stuyfzand (1993).

As mentioned in chapter 5.2, solute concentrations generally do not show an increase with depth within the freshwater lens. Differences between the shallow and medium observation well in Fig. 10 are not identifiable, whereas $\mathrm{Na}-\mathrm{Cl}$ concentrations are increasing remarkably shortly above the clay layer. $\mathrm{Ca}^{2+}$ and $\mathrm{HCO}_{3}^{-}$ions dominate in the freshwater lens, which is a typical result of calcite dissolution (Appelo and Postma, 2005). Typically, intruding sea- or freshwater leads to cation exchange by displacing either $\mathrm{Ca}$ or $\mathrm{Na}$. In order to identify if an aquifer is salinizing or freshening, Stuyfzand $(1989,2008)$ proposed the Base Exchange index (BEX):

$\mathrm{BEX}=\mathrm{Na}+\mathrm{K}+\mathrm{Mg}-1.0716 * \mathrm{Cl}$

with $\mathrm{Na}, \mathrm{K}, \mathrm{Mg}$ and $\mathrm{Cl}$ in [meq/L] and $1.0716=(\mathrm{Na}+\mathrm{K}+\mathrm{Mg}) / \mathrm{Cl}$ in mean ocean water. A negative BEX indicates a salinizing trend while a positive BEX indicates freshening if base exchange is the only process. The Base Exchange index has been calculated for all samples (Table 2). It can be seen, that except for one (26A), all shallow and medium observation wells show positive values marking a freshening trend. Regarding the deep observation wells $C$, most of them indicate freshening as well. BEX is for sample 27C from the transition zone also slightly above zero, pointing towards freshening.

At the transition zone, mixing of seawater (Na-Cl-type) with freshwater $\left(\mathrm{CaHCO}_{3}\right.$-type $)$ occurs. Since chloride is a conservative parameter in water, it can be used to calculate the fraction of seawater in the brackish groundwater sample of the transition zone (27C). Assuming an average $\mathrm{Cl}^{-}$concentration of $566 \mathrm{mmol} /$ 1 in the seawater, the fraction of seawater in the brackish sample is then given by:

$f_{\text {sea }}=m_{\mathrm{Cl}^{-}, \text {sample }} / 566$

with $f_{\text {sea }}=$ fraction of seawater; $m_{\mathrm{Cl}^{-} \text {, sample }}=\mathrm{Cl}^{-}$concentration in $\mathrm{mmol} / \mathrm{l}$ (Appelo and Postma, 2005). The resulting ratio is 6\% seawater to $94 \%$ freshwater. Thus, freshwater is still dominating at that depth.

Seawater below the clay layer shows a typical dominance of $\mathrm{NaCl}$, but as mentioned in the previous chapter, an influence of the above lying freshwater lens is expected. This influence can be approximated by taking the sea surface chloride concentration $(18,000 \mathrm{mg} / \mathrm{l})$ as a reference and calculate the mixing ratio between the medium observation wells $\mathrm{B}$ in the freshwater lens $(\mathrm{Cl}=58.8 \mathrm{mg} / \mathrm{l})$ and the deep observation wells $\mathrm{C}\left(\mathrm{Cl}_{\min }=11,700\right.$ $\mathrm{mg} / \mathrm{l}, \mathrm{Cl}_{\max }=17,550 \mathrm{mg} / \mathrm{l}$ ), excluding 27C (Appelo and Postma, 2005 ). The resulting freshwater fraction lies between $2 \%$ and $35 \%$, depending on the different mixtures for each deep observation well C. Similar calculations with the electrical conductivity result in a freshwater fraction of $3-23 \%$. This indicates a significant influence of freshwater below the clay layer. Thus, it is very likely that the clay layer is not completely impervious.

As shown in Fig. 10, the freshwater lens is assumed to have an asymmetric shape in horizontal direction due to geomorphologic patterns. Groundwater recharge takes place preferentially below the highly permeable dunes and only marginally below low permeable salt marsh areas. Additionally, the embedded clay layer between 44 and $55 \mathrm{mbsl}$ is supposed to generally inhibit further expansion of freshwater in the vertical direction. In fact, a further expansion in vertical direction up to a freshwater thickness of $\sim 80 \mathrm{~m}$ would be expected, taking into consideration the 
Table 2

Electric conductivity (EC), temperature $(\mathrm{T}), \mathrm{pH}$ and concentrations of the major elements for all samples; $\mathrm{n}$ gives the quantity of included samples.

\begin{tabular}{|c|c|c|c|c|c|c|c|c|c|c|c|c|c|}
\hline Sample & Sample type & $\begin{array}{l}\mathrm{EC}(\mu \mathrm{S} / \\
\mathrm{cm})\end{array}$ & $\begin{array}{l}\mathrm{T} \\
\left({ }^{\circ} \mathrm{C}\right)\end{array}$ & $\mathrm{pH}$ & $\begin{array}{l}\text { BEX (meq/ } \\
\text { L) }\end{array}$ & $\begin{array}{l}\mathrm{Na}^{+}(\mathrm{mg} / \\
\mathrm{l})\end{array}$ & $\begin{array}{l}\mathrm{Ca}^{2+}(\mathrm{mg} / \\
\mathrm{l})\end{array}$ & $\begin{array}{l}\mathrm{Mg}^{2+}(\mathrm{mg} / \\
\mathrm{l})\end{array}$ & $\begin{array}{l}\mathrm{K}^{+}(\mathrm{mg} / \\
\mathrm{l})\end{array}$ & $\begin{array}{l}\mathrm{Cl}^{-}(\mathrm{mg} / \\
\mathrm{l})\end{array}$ & $\begin{array}{l}\mathrm{HCO}_{3}^{-}(\mathrm{mg} / \\
\text { l) }\end{array}$ & $\begin{array}{l}\mathrm{SO}_{4}^{2-}(\mathrm{mg} / \\
\mathrm{l})\end{array}$ & $\mathrm{n}$ \\
\hline FB1 & Product. well & 694 & 10.6 & 8.4 & 2.1 & 76.7 & 44.4 & 18.9 & 11.5 & 102.0 & 225.7 & 24.1 & 1 \\
\hline FB2 & Product. well & 392 & 10.0 & 8.0 & 0.8 & 33.5 & 40.9 & 8.2 & 4.1 & 49.0 & 158.6 & 11.8 & 2 \\
\hline FB3 & Product. well & 611 & 10.8 & 7.7 & 1.1 & 54.0 & 52.5 & 13.3 & 9.6 & 84.7 & 237.9 & 22.9 & 1 \\
\hline FB4 & Product. well & 597 & 10.4 & 8.3 & 1.2 & 63.0 & 37.0 & 16.4 & 8.0 & 101.3 & 164.7 & 25.2 & 1 \\
\hline FB5 & Product. well & 520 & 10.2 & 8.2 & 1.3 & 45.9 & 34.7 & 14.4 & 7.1 & 68.8 & 158.6 & 17.9 & 1 \\
\hline FB6 & Product. well & 421.5 & 10.3 & 8.2 & 0.8 & 35.7 & 43.7 & 8.3 & 3.6 & 50.2 & 170.8 & 13.1 & 2 \\
\hline FB7 & Product. well & 389 & $\mathrm{n} / \mathrm{a}$ & $\begin{array}{l}\mathrm{n} / \\
\mathrm{a}\end{array}$ & 1.8 & 34.0 & 29.0 & 13.6 & 16.0 & 40.9 & 189.1 & 9.2 & 1 \\
\hline $25 \mathrm{~A}$ & $\begin{array}{l}\text { Shallow obs. } \\
\text { well }\end{array}$ & 396 & 10.9 & 8.3 & 0.7 & 30.1 & 44.0 & 9.4 & 3.9 & 49.0 & 158.6 & 9.1 & 1 \\
\hline $26 \mathrm{~A}$ & $\begin{array}{l}\text { Shallow obs. } \\
\text { well }\end{array}$ & 1447 & 10.7 & 8.6 & -0.8 & 180 & 63.3 & 17.0 & 7.4 & 338.0 & 122.0 & 61.5 & 1 \\
\hline $27 \mathrm{~A}$ & $\begin{array}{l}\text { Shallow obs. } \\
\text { well }\end{array}$ & 383 & 11.1 & 8.1 & 1.2 & 28.9 & 19.0 & 16.9 & 8.8 & 54.9 & 134.2 & 4.6 & 1 \\
\hline $28 \mathrm{~A}$ & $\begin{array}{l}\text { Shallow obs. } \\
\text { well }\end{array}$ & 420.5 & 11.0 & 8.0 & 0.7 & 26.7 & 57.5 & 6.6 & 2.1 & 38.5 & 192.2 & 12.6 & 2 \\
\hline $29 \mathrm{~A}$ & $\begin{array}{l}\text { Shallow obs. } \\
\text { well }\end{array}$ & 383 & 10.0 & 8.3 & 0.7 & 33.6 & 31.4 & 8.8 & 4.6 & 54.5 & 122.0 & 16.1 & 1 \\
\hline $30 \mathrm{~A}$ & $\begin{array}{l}\text { Shallow obs. } \\
\text { well }\end{array}$ & 406 & 10.8 & 8.5 & 0.7 & 48.0 & 39.0 & 8.3 & 3.6 & 71.6 & 146.4 & 15.2 & 1 \\
\hline $31 \mathrm{~A}$ & $\begin{array}{l}\text { Shallow obs. } \\
\text { well }\end{array}$ & 589 & 10.4 & 8.1 & 0.2 & 45.6 & 74.2 & 8.1 & 3.6 & 85.1 & 237.9 & 6.4 & 2 \\
\hline $25 B$ & $\begin{array}{l}\text { Medium obs. } \\
\text { well }\end{array}$ & 809.5 & 10.8 & 8.2 & 2.1 & 179.6 & 31.7 & 33.9 & 15.9 & 292.9 & 198.3 & 63.7 & 2 \\
\hline $26 \mathrm{~B}$ & $\begin{array}{l}\text { Medium obs. } \\
\text { well }\end{array}$ & 635 & 10.8 & 8.2 & 2.6 & 60.1 & 33.8 & 29.3 & 12.0 & 90.0 & 219.6 & 54.7 & 1 \\
\hline 27B & $\begin{array}{l}\text { Medium obs. } \\
\text { well }\end{array}$ & 338 & 11.1 & 8.0 & 1.5 & 29.9 & 16.8 & 15.7 & 10.1 & 43.1 & 146.4 & 6.1 & 1 \\
\hline 28B & $\begin{array}{l}\text { Medium obs. } \\
\text { well }\end{array}$ & 392 & 10.7 & 8.3 & 1.1 & 34.4 & 31.3 & 13.6 & 6.6 & 56.6 & 158.6 & 20.7 & 2 \\
\hline $29 B$ & $\begin{array}{l}\text { Medium obs. } \\
\text { well }\end{array}$ & 371 & 10.3 & 8.3 & 1.4 & 40.8 & 29.0 & 17.5 & 8.7 & 66.2 & 158.6 & 21.4 & 1 \\
\hline 30B & $\begin{array}{l}\text { Medium obs. } \\
\text { well }\end{array}$ & 393 & 10.4 & 8.3 & 1.1 & 34.5 & 26.2 & 12.8 & 7.2 & 54.6 & 122.0 & 27.4 & 2 \\
\hline 31B & $\begin{array}{l}\text { Medium obs. } \\
\text { well }\end{array}$ & 561 & 10.4 & 8.0 & 0.7 & 36.3 & 59.0 & 1.6 & 7.6 & 42.5 & 201.3 & 19.0 & 1 \\
\hline $25 C$ & Deep obs. well & 44300 & 11.3 & 6.3 & 8.3 & 7470 & 124 & 352 & 315 & 11700 & 238 & 2110 & 1 \\
\hline $26 C$ & Deep obs. well & 41400 & 11.2 & 6.6 & 8.5 & 7740 & 118 & 326 & 302 & 12000 & 281 & 1980 & 1 \\
\hline $27 C$ & Deep obs. well & 4570 & 11.3 & 6.9 & 0.7 & 764 & 8.5 & 21.8 & 40.6 & 1170.0 & 54.9 & 94.5 & 1 \\
\hline $28 \mathrm{C}$ & Deep obs. well & 39950 & 11.2 & 6.3 & 9.4 & 7150 & 314 & 634 & 334 & 11985 & 226 & 1995 & 2 \\
\hline $29 C$ & Deep obs. well & 48500 & 10.6 & 7.0 & 16.0 & 9630 & 181 & 461 & 376 & 14900 & 238 & 2160 & 1 \\
\hline $30 C$ & Deep obs. well & 39000 & 10.4 & 6.8 & -10.3 & 8280 & 325 & 930 & 381 & 15110 & 305 & 2486 & 1 \\
\hline $31 \mathrm{C}$ & Deep obs. well & 46700 & 10.3 & 7.5 & 25.1 & 10200 & 480 & 1218 & 458 & 17550 & 256 & 2792 & 1 \\
\hline 01 & Surface water & 658.5 & 16.1 & 7.8 & 2.6 & 59.7 & 38.7 & 24.9 & 15.2 & 79.5 & 289.8 & 8.4 & 2 \\
\hline $\mathrm{O} 2$ & Surface water & 860 & 24.0 & 7.9 & 0.7 & 44.7 & 65.5 & 10.0 & 13.4 & 78.1 & 250.1 & 16.9 & 1 \\
\hline $\mathrm{O} 3$ & Surface water & 694 & 21.0 & 7.8 & 1.5 & 77.6 & 29.8 & 16.2 & 4.9 & 109.0 & 128.1 & 53.1 & 1 \\
\hline 04 & Surface water & 340 & 18.5 & 6.9 & 0.4 & 31.1 & 33.5 & 4.6 & 5.2 & 49.6 & 122.0 & 16.0 & 1 \\
\hline 05 & Surface water & 173 & 16.6 & 6.9 & 0.2 & 8.1 & 16.1 & 2.6 & 4.7 & 15.9 & 48.8 & 10.3 & 1 \\
\hline 06 & Surface water & 1094 & 20.6 & 9.6 & 0.2 & 152 & 13.9 & 16.8 & 14.9 & 269 & 54.9 & 47.2 & 1 \\
\hline 07 & Surface water & 6880 & $\mathrm{n} / \mathrm{a}$ & $\begin{array}{l}\mathrm{n} / \\
\mathrm{a}\end{array}$ & -10.5 & 900 & 177 & 140.7 & 60.5 & 2076 & $\mathrm{n} / \mathrm{a}$ & 298 & 1 \\
\hline 08 & Surface water & 2430 & 20.2 & 7.1 & 1.7 & 369 & 16.6 & 35.3 & 29.2 & 594 & 54.9 & 104 & 1 \\
\hline S1 & Seawater & 47600 & $\mathrm{n} / \mathrm{a}$ & $\begin{array}{l}\mathrm{n} / \\
\mathrm{a}\end{array}$ & 7.8 & 8575 & 380 & 1188 & 433 & 15680 & $\mathrm{n} / \mathrm{a}$ & 2694 & 1 \\
\hline S2 & Seawater & 50200 & 19.9 & 8.3 & -5.2 & 8950 & 374 & 1150 & 376 & 16500 & 177 & 2590 & 1 \\
\hline N7 & Prec. & 146 & $\mathrm{n} / \mathrm{a}$ & 4.9 & & 18.8 & 1.7 & $<2,0$ & $<5,0$ & 33.1 & $\mathrm{n} / \mathrm{a}$ & 6.26 & - \\
\hline N8 & Prec. & 43 & $\mathrm{n} / \mathrm{a}$ & 5.0 & & 5.36 & $<1,0$ & $<2,0$ & $<5,0$ & 8.39 & $\mathrm{n} / \mathrm{a}$ & 2.3 & - \\
\hline N9 & Prec. & 61 & $\mathrm{n} / \mathrm{a}$ & 4.6 & & 6.22 & $<1,0$ & $<2,0$ & $<5,0$ & 11.6 & $\mathrm{n} / \mathrm{a}$ & 2.42 & - \\
\hline N10 & Prec. & 72 & $\mathrm{n} / \mathrm{a}$ & 5.1 & & 10.31 & $<1,0$ & $<2,0$ & $<5,0$ & 20.3 & $\mathrm{n} / \mathrm{a}$ & 3.68 & - \\
\hline
\end{tabular}

Ghyben-Herzberg relationship (Herzberg, 1901). The resulting shape is more extended in horizontal direction and the boundaries between freshwater and seawater are expected to be steeper compared to a "free" freshwater lens (Beukeboom, 1976).

\section{Conclusions}

This study gives a compact overview of the groundwater ages, recharge conditions and hydrochemistry of a barrier island freshwater lens. It focuses on the freshwater lens below the main dune arc in the western part of Spiekeroog Island. Groundwater ages could be determined for two depths within the freshwater lens and in the underlying saltwater. The results indicate increasing groundwater ages with increasing depth and also from the center of the main freshwater lens to the sides. A recharge rate of $300-400 \mathrm{~mm} / \mathrm{a}$ is calculated from the apparent ${ }^{3} \mathrm{H}-{ }^{3} \mathrm{He}$ ages on the basis of one observation well near the center of the freshwater lens and an average groundwater travel time in the freshwater lens of 35-46 years can be estimated. Stable isotope analyses provided insight on groundwater and surface water origin. A slight influence of river input is assumed for the sea surface water. The isotopic signatures of the freshwater lens reflect long-term annual 
precipitation averages. A slight depletion of heavy oxygen isotopes with depth could be the result of a slight temperature increase in the last 30 years. The transition zone between freshwater and saltwater was identified at a depth of about $44 \mathrm{mbsl}$ at the margin of the lens. Lower salinities and a depletion in heavy oxygen isotopes for the saltwater below the freshwater lens compared to the sea surface water are assumed to result from an influence of the above lying freshwater lens. Moreover, it is suggested, that the clay layer, which is supposed to act as aquitard, is not completely impervious.

The freshwater lens is mainly composed of $\mathrm{Ca}-\mathrm{Na}-\mathrm{HCO}_{3}-\mathrm{Cl}-$ water and $\mathrm{Na}-\mathrm{Ca}-\mathrm{Mg}-\mathrm{HCO}_{3}-\mathrm{Cl}$-water. Except one, all samples from observation wells in the freshwater lens show a freshening trend.

In conclusion, the results allowed for the generation of a conceptual model on the hydrochemical evolution from recharge to discharge of a barrier island freshwater lens. Due to geomorphologic patterns, these freshwater lenses are believed to have an asymmetric shape in the horizontal direction, reaching its maximum thickness below the highest dunes. In case of Spiekeroog, the vertical expansion is also significantly reduced by the clay layer at $44 \mathrm{mbsl}$. This leads to further lateral extension of the freshwater lens in the horizontal direction and steeper boundaries between freshwater and saltwater.

\section{Acknowledgements}

The authors wish to thank the Oldenburg-Ostfriesischer Wasserverband (OOWV), especially André Göken for his generous support at every visit on Spiekeroog and Rheinard Hövel, Silke Bücker and Markus Penning for the good cooperation and the permission to use and access wells and data. We thank the Nationalparkverwaltung Niedersächsisches Wattenmeer, especially Gerald Millat. We would also like to thank Birgit Schade from the Gemeinde Spiekeroog and Swaantje Fock from the Umweltzentrum Spiekeroog for their kind help during sampling. Further thanks to Ulrike Kücks for laboratory support as well as Lutz Schoenicke and Cindy Springer for help with stable isotope analyses.

\section{References}

Appelo, C.A.J., Postma, D., 2005. Geochemistry, Groundwater and Pollution, second ed. CRC Press, Taylor \& Francis Group, Amsterdam.

Barckhausen, J., 1969. Entstehung und Entwicklung der Insel Langeoog - Beiträge zur Quartärgeologie und Paläogeographie eines ostfriesischen Küstenabschnittes. Diss. TU Carolo-Wilhelmina zu Braunschweig, Oldenburge Jb. 68, 239-281.

Beukeboom, Th.J., 1976. The Hydrology of the Frisian islands. Editions Rodopi NV Amsterdam.

Bourg, C., Stievenard, M., Jouzel, J., 2001. Hydrogen and oxygen isotopic composition of aqueous salt solutions by gas-water equilibration method. Chem. Geol. 173 331-337.

Chesnaux, R., Allen, D.M., 2008. Groundwater travel times for unconfined island aquifers bounded by freshwater or seawater. Hydrogeol. J. 16, 437-445.

Christensen, J.H., Hewitson, B., Busuioc, A., Chen, A., Gao, X., Held, I., Jones, R., Kolli, R.K., Kwon, W.T., Laprise, R., Magaña Rueda, V., Mearns, L., Menéndez, C.G. Räisänen, J., Rinke, A., Sarr, A., Whetton, P., 2007. Regional climate projections. In: Solomon, S., Qin, D., Manning, M., Chen, Z., Marquis, M., Averyt, K.B., Tignor, M., Miller, H.L. (Eds.), Climate Change 2007: The Physical Science Basis. Contribution of Working Group I to the Fourth Assessment Report of the Intergovernmental Panel on Climate Change. Cambridge University Press, Cambridge, United Kingdom and New York, NY, USA.

Clark, I., Fritz, P., 1997. Environmental Isotopes in Hydrogeology. CRC Press LLC.

CWSS (Common Wadden Sea Secretariat, Wilhelmshaven, Germany), WHNPC (World Heritage Nomination Project Group), 2008. Nomination of the DutchGerman Wadden Sea as World Heritage Site. Plakativ Grafische Medien GmbH Kirchhatten.

DIN EN ISO 10304-2 (Deutsche Industrienorm), 2009. Wasserbeschaffenheit Bestimmung von gelösten Anionen mittels Flüssigkeits-Ionenchromatographie - Teil 1: Bestimmung von Bromid, Chlorid, Fluorid, Nitrat, Nitrit, Phosphat und Sulfat (ISO 10304-1:2007); Deutsche Fassung EN ISO 10304-1:2009.

DIN 38406 (Deutsche Industrienorm), 2009. Deutsche Einheitsverfahren zur Wasser-, Abwasser- und Schlammuntersuchung - Kationen (Gruppe E) - Teil 17: Bestimmung von Uran - Verfahren mittels adsorptiver StrippingVoltammetrie in Grund-, Roh- und Trinkwässern (E 17).
Duinker, J., Hillebrand, M.T.J., Nolting, R.F., 1982. The river Weser: processes affecting the behavior of metals and organochlorines during estuarine mixing. Neth. J. Sea Res. 15 (2), 170-195.

Duinker, J.C., Hillebrand, M.T.J., Nolting, R.F., 1985. The river Ems: processes affecting the behavior of metals and organochlorines during estuarine mixing. Neth. J. Sea Res. 19 (1), 19-29.

Eitner, V., 1996. Morphological and sedimentological development of a tidal inlet and its catchment area (Otzumer Balje, southern North Sea). J. Coast. Res. 12, 271-293.

Fetter, C.W., 1972. Position of the saline water interface beneath oceanic islands. Water Resour. Res. 8 (5), 1307-1315.

Fitzgerald, D.M., Penland, S., Nummedal, D., 1984. Control of barrier island shape by inlet sediment bypassing: Eastfrisian Islands, west Germany. Mar. Geol. 60, 355-376.

Flemming, B.W., 2002. Effects of climate and human interventions on the evolution of the Wadden Sea depositional system (southern North Sea). In: Wefer, G. Berger, W., Behre, K.-E., Jansen, E. (Eds.), Climate Development and History of the North Atlantic Realm. Springer-Verlag Berlin Heidelberg New York.

Grootjans, A.P., Sival, F.P., Stuyfzand, P.J., 1996. Hydro-geochemical analysis of a degraded dune slack. Vegetatio 126, 27-38.

Harwood, A.J., Dennis, P.F., Marca, A.D., Pilling, G.M., Millner, R.S., 2008. The oxygen isotope composition of water masses within the North Sea. Est. Coast. Shelf Sci. 78, 353-359.

Herzberg, A., 1901. Die Wasserversorgung einiger Nordseebäder. J. Gasbeleucht. Wasserversorg. 44, 815-819.

Horita, J., Wesolowski, D.J., Cole, D.R., 1993. The activity-compostion relationship of oxygen and hydrogen isotopes in aqueous salt solutions: I. Vapor-liquid water equilibration of single salt solutions from 50 to $100^{\circ} \mathrm{C}$. Geochim. Cosmochim. Acta 57, 2797-2817.

IAEA, 2011. Isotope hydrology information system. The GNIP database. <http:// www.iaea.org/water>. (cited 12.11).

IPCC. Solomon, S., Qin, D., Manning, M., Chen, Z., Marquis, M., Averyt, K.B., Tignor, M., Miller, H.L. (Eds.), 2007. Contribution of Working Group I to the Fourth Assessment Report of the Intergovernmental Panel on Climate Change. Cambridge University Press, Cambridge, United Kingdom and New York, NY, USA.

Kipfer, R., Aeschbach-Hertig, W., Peeters, F., Stute, M., 2002. Noble gases in geochemistry and cosmochemistry. In: Porcelli, D., Ballentine, C., Wieler, R. (Eds.), Reviews in Mineralogy and Geochemistry, vol. 47. Mineralogical Society of America, Washington, DC, pp. 614-699.

Kohfahl, C., Rodriguez, M., Fenk, C., Menz, C., Benavente, J., Hubberten, H., Meyer, H., Paul, L., Knappe, A., Lopez-Geta, J.A., Pekdeger, A., 2008. Characterising flow regime and interrelation between surface-water and ground-water in the Fuente de Piedra salt lake basin by means of stable isotopes, hydrogeochmical and hydraulic data. J. Hydrol. 351, 170-187.

Lenhardt, H.J., Radach, G., Ruardij, P., 1997. The effects of river input on the ecosystem dynamics in the continental coastal zone of the North Sea using ERSEM. J. Sea Res. 38, 249-274.

Mackenzie, B.R., Schiedek, D., 2007. Daily ocean monitoring since the 1860 s shows record warming of Northern European seas. Global Change Biol. 13, 1335-1347.

Marggraf, G., 2005. Geogene und anthropogene Einflüsse auf ein isoliertes System (Düneninseln) in Bezug auf die Hydrochemie des Grundwassers. Diss. TU Carolo-Wilhelmina zu Braunschweig.

Marggraf, G., Naumann, K., 2003. Hydrogeologie und grundwasserdynamik. In: Petersen, J., Pott, R., Janiesch, P., Wolff, J. (Eds.), Umweltverträgliche Grundwasserbewirtschaftung in hydrogeologisch und ökologisch sensiblen Bereichen der Nordseeküste. Husum Druck- und Verlagsgesellschaft mbH u. Co, KG, Husum.

Meyer, H., Schönicke, L., Wand, U., Hubberten, H.-W., Friedrichsen, H., 2000. Isotope studies of hydrogen and oxygen in ground ice-experiences with the equilibration technique. Isotopes Environ. Health Stud. 36, 133-149.

Nationalparkverwaltung Niedersächsisches Wattenmeer, 2011. Lebensraumkartierung. <http://www.nationalpark-wattenmeer.de> (cited 12.11).

NIBIS Kartenserver, 2011. Hydrogeologische Karte von Niedersachsen 1:200,000 Grundwasserneubildung, Methode GROWA06V2, Landesamt für Bergbau, Energie und Geologie, Hannover. Cited December 2011.

NLWKN (Niedersächsicher Landesbetrieb für Wasserwirtschaft, Küstenschutz und Naturschutz), 2010. Generalplan Küstenschutz Niedersachsen - Ostfriesische Inseln.

NLfB (Niedersächsisches Landesamt für Bodenforschung), unpublished results, 1985. Gutachterlicher Bericht über die Ergebnisse der Grundwassererkundung auf der Insel Spiekeroog.

ooWV (Oldenburg-Ostfriesischer Wasserverband), 2009. Wasserrechtsantrag. Antrag auf Bewilligung einer Grundwasserentnahme über $180.000 \mathrm{~m}_{3} / \mathrm{a}$ für das Wasserwerk Spiekeroog.

Parkhurst, D.L., Appelo, C.A.J., 1999. User's guide to PHREEQC (version 2) - a computer program for speciation, reaction-path, 1D-transport, and inverse geochemical calculations. US Geol. Surv. Water Resour. Inv. Rep. 99-4259, 312p.

Post, V.E.A., 2005. Fresh and saline groundwater interaction in coastal aquifers: is our technology ready for the problems ahead? Hydrogeol. J. 13, 120-123.

Roether, W., 1967. Estimating the tritium input to groundwater from wine samples: groundwater and direct run-off contribution to central European surface waters. In: IAEA. Isotopes in hydrology, Vienna, pp. 73-91.

Scheurle, C., Hebbeln, D., 2003. Stable oxygen isotopes as recorders of salinity and river discharge in the German Bight. North Sea. Geo-Mar Lett. 23, 130-136. 
186

T. Röper et al./Journal of Hydrology 454-455 (2012) 173-186

Scheurle, C., Hebbeln, D., Jones, P., 2005. An 800-year reconstruction of Elbe River discharge and German Bight sea-surface salinity. Holocene 15, 429-434.

Schneider, J.C., Kruse, S.E., 2005. Assessing selected natural and anthropogenic impacts on freshwater lens morphology on small barrier islands: Dog Island and St. George Island, Florida. USA Hydrogeol. J. 14, 131-145.

Sengpiel, K.-P., Meiser, P., 1981. Locating the freshwater/salt water interface on the island of spiekeroog by Airborne EM resistivity“/depth mapping. Geol. Jhrb. C 29, 255-271.

Sindowski, K.H., 1970. Erläuterungen zu Blatt Spiekeroog Nr. 2212. Niedersächsisches Landesamt für Bodenforschung, Hannover.

Sindowski, K.H., 1973. Das ostfriesische Küstengebiet. Inseln, Watten und Marschen. Gebrüder Borntraeger, Berlin-Stuttgart.

Sival, F.P., Grootjans, A.P., Stuyfzand, P.J., Verschoore de la Houssaye, T., 1997. Variation in groundwater composition and decalcification depth in a dune slack: effects on basiphilous vegetation. J. Coast. Conserv. 3, 79-86.

Solomon, D.K., Cook, P.C., 2000. ${ }^{3} \mathrm{H}$ and ${ }^{3}$ He. In: Cool, P.J., Herczeg, A.L. (Eds.), Environmental Tracers in Subsurface Hydrology. Kluwer, Dordrecht, The Netherlands.

Staneva, J., Stanev, E.V., Wolff, J.O., Badewien, T.H., Reuter, R., Flemming, B., Bartholomä, A., Bolding, K., 2008. Hydrodynamics and sediment dynamics in the German Bight. In: A focus on observations and numerical modeling in the East Frisian Wadden Sea. Continental Shelf Research doi: 10.1016/ j.csr.2008.01.006.

Streif, H., 1990. Das ostfriesische Küstengebiet. Nordsee, Inseln, Watten und Marschen. Sammlung geologischer Führer, Gebrüder Borntraeger, BerlinStuttgart.

Streif, H., 2002. The pleistocene and holocene development of the southeastern north sea basin and adjacent coastal areas. In: Wefer, G., Berger, W., Behre, K.-E. Jansen, E. (Eds.), Climate Development and History of the North Atlantic Realm. Springer Berlin Heidelberg, pp. 387-397.

Stuyfzand, P.J., 2008. Base exchange indices as indicators of salinization or freshening of (coastal) aquifers. In: Program and Proceedings 20th Salt Water
Intrusion Meeting, June 23-27 2008, Naples (Fl) USA, Univ Florida, IFAS Research, pp. 262-265.

Stuyfzand, P.J., 1993. Hydrochemistry and Hydrology of the coastal Dune Area of the western Netherlands. Diss. Vrije Universiteit of Amsterdam, published by KIWA N.V., ISBN 90-74741-01-0, 366 p. <http://dare.ubvu.vu.nl/handle/1871/12716>. Stuyfzand, P.J., 1989. A new hydrochemical classification of watertypes. IAHS Publ. 182, 89-98.

Sültenfuß, J., Rhein, M., Roether, W., 2009. The Bremen mass spectrometric facility for the measurement of helium isotopes, neon and tritium in water. Isot. Environ. Health. Stud. 45 (2), 1-13.

Tolstikhin, I.N., Kamenskij, I.L., 1969. Determination of groundwater ages by the $\mathrm{T}-{ }^{3}$ He method. Geochem. Int. 6, 810-811.

Tronicke, J., unpublished diploma thesis, 1997. Geophysikalische Erkundung von Süßwasservorkommen und Infiltrationszonen in Inselaquiferen, Institut für Geophysik der Westfälischen Wilhelms-Universität Münster.

Tronicke, J., Blindow, N., Groß, R., Lange, M.A., 1999. Joint application of surface electrical resistivity- and GPR-measurements for groundwater exploration on the island of Spiekeroog - Northern Germany. J. Hydrol 223, 44-53.

Vacher, H.L., Bengtsson, T.O., Plummer, L.N., 1990. Hydrology of meteoric diagenesis: residence time of meteoric ground water in island freshwater lenses with application to aragonite-calcite stabilization rate in Bermuda. Geol. Soc. of Am. Bull 102, 223-232.

Vacher, H.L., 1988. Dupuit-Ghyben-Herzberg analysis of strip-island lenses. Geol. Soc. Am. Bull. 100, 580-591.

Vandenbohede, A., Lebbe, L., 2005. Occurrence o salt water above fresh water in dynamic equilibrium in a coastal groundwater flow system near De Panne, Belgium. Hydrogeol. J. 14, 462-472.

Van der Veer, P., 1977. Analytical solution for a two-fluid flow in a coastal aquifer involving a phreatic surface with precipitation. J. Hydrol. 35, 271-278.

White, I., Falkland, T., 2009. Management of freshwater lenses on small Pacific islands. Hydrogeol. J. http://dx.doi.org/10.1007/s10040-009-0525-0. 